\title{
Studies Towards the Construction of Alkylidene Quinolizidines. The Total Synthesis of Homopumiliotoxin 223G
}

\author{
Leonardo S. Santos and Ronaldo A. Pilli* \\ Instituto de Química, Universidade Estadual de Campinas, CP 6154 13083-970 Campinas - SP, Brazil
}

\begin{abstract}
A adição de 5-metil-2-tri-isopropilsililoxifurano (5) a $N$-carbobenziloxi-2-metoxipiperidina (6a) forneceu uma mixtura dos isômeros eritro e treo $\mathbf{7 a}$ and $\mathbf{8 a}$, respectivamente, em rendimentos de moderado a bom (42-85\%) e razão diastereoisomérica (7a: : 8a) variando entre 1,1:1 -6:1, dependendo do sistema de solvente e do ácido de Lewis empregados. O isômero treo $8 \mathbf{a}$ foi transformado na (+/-)-homopumiliotoxina 223G (1) que foi obtida a partir de $\mathbf{6 a}$ em 5 etapas e $13 \%$ de rendimento total.
\end{abstract}

The addition of 5-methyl-2-triisopropylsilyloxyfuran (5) to $\mathrm{N}$-carbobenzyloxy-2methoxypiperidine (6a) afforded a mixture of the corresponding erythro and threo isomers $7 \mathbf{a}$ and 8a, respectively, in moderate to good yields $(42-85 \%)$ and diastereoisomeric ratio (7a : 8a) ranging from 1.1:1-6:1 depending on the solvent system and the Lewis acid employed. The threo isomer $\mathbf{8 a}$ was eventually converted to (+/-)-homopumiliotoxin $223 \mathrm{G}(\mathbf{1})$ which was prepared in 5 steps and $13 \%$ overall yield from $\mathbf{6 a}$.

Keywords: homopumiliotoxin 223G, $N$-acyliminium ions, silyloxyfuran, vinylogous addition

\section{Introduction}

A wide range of biologically active compounds is found in the skin secretions of amphibians. Many of these alkaloids have unique profiles of pharmacological activities and therapeutic potential. A remarkable variety of alkaloids have been isolated from skin extracts of the frogs of the Dendrobatidae family, which are used as antimicrobial agent and chemical defense against predators. It appears likely that all of the frog skin alkaloids are taken up from diet, which for such amphibians consists mainly of small arthropods. ${ }^{1}$ Homopumiliotoxins $223 \mathrm{G}$ (1), 235C, 319A, 319B and 321B (Figure 1) featuring a quinolizidine core have been isolated in such minute amounts from Dendrobatidae frogs which precluded the structural elucidation of several representatives to be carried out. ${ }^{2}$

Prior to our efforts in this area, a single synthetic route to homopumiliotoxin $223 \mathrm{G}$ (1) had been reported by Kibayashi and coworkers ${ }^{3}$ along the synthetic scheme depicted in Figure 2. The construction of the quaternary

* e-mail: pilli@iqm.unicamp.br

This paper is dedicated to Prof. Albert J. Kascheres on occasion of his $60^{\text {th }}$ birthday

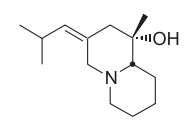

Homopumiliotoxin 223G (1)

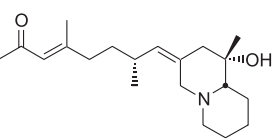

Homopumiliotoxin $319 \mathrm{~B}$

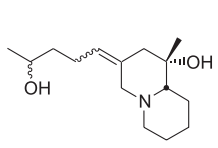

Homopumiliotoxin $235 \mathrm{C}$

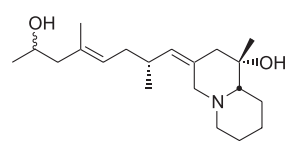

Homopumiliotoxin 321B

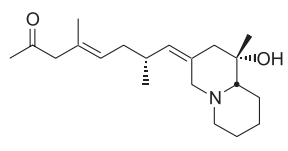

Homopumiliotoxin 319A
Figure 1. Representative homopumiliotoxins isolated from Dendrobatidae frogs.

stereogenic center was centered around the $\mathrm{TiCl}_{4}$-mediated addition of allenylsilanes to a methyl ketone derived from $(S)$-pipecolic acid. After hydrostannylation of the triple bond and iodine-tin exchange, the construction of the quinolizidine ring incorporating the $(Z)$-alkylidene side chain was achieved through palladium-catalyzed carbonylation of the vinyl iodide intermediate. ${ }^{3}$

Our approach to homopumiliotoxin 223 (1) is based on the preparation of bicyclic lactam $\mathbf{2 a}$ through the addition of 5-methylsilyloxyfuran $\mathbf{5}$ to an $N$-acyliminium ion 4 , followed by the installation of the $(Z)$-alkylidene side chain based on a stereoselective aldol reaction followed by stereospecific elimination (Figure 3). ${ }^{4}$ 


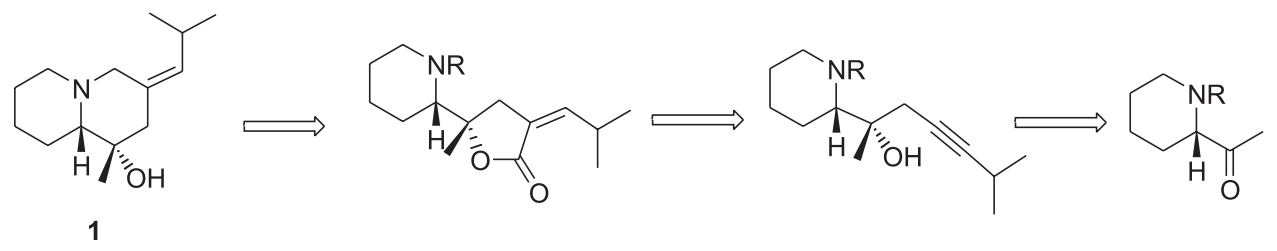

Figure 2. Synthetic approach to homopumiliotoxin 223 G (1) by Kibayashi and coworkers.<smiles>[R]OCN1CCCC[C@H]1[C@]1([R4])C=CC(=O)O1</smiles>

Figure 3. Synthetic approach to homopumiliotoxin $223 \mathrm{G}$ (1) based on vinylogous Michael addition to $N$-acyliminium ions.

\section{Results and Discussion}

As previously reported by Morimoto for the addition of silyloxyfurans to 5-membered ring $N$-acyliminium ions, we also observed that the diastereoselectivity was not significantly affected by the nature of the Lewis acid, except when TMSOTf was employed which afforded the best erythro:threo ratio (6:1) in $80 \%$ yield in $\mathrm{CH}_{2} \mathrm{Cl}_{2} / \mathrm{THF}^{4-6}$ Additionally, the hitherto not observed regioisomer $\mathbf{9 b}$ (relative configuration not determined) was formed when $\mathrm{N}$-Boc precursor of the $\mathrm{N}$-acyliminium ion was employed

Table 1. Addition of 5-methylsilyloxyfuran (5) to $N$-acyliminium ions

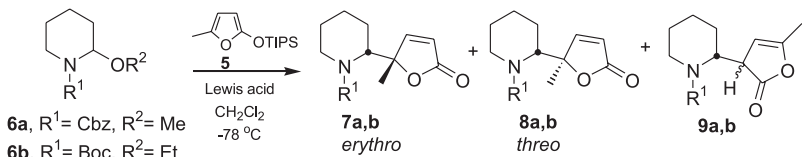

\begin{tabular}{cccccc}
\hline Entry & $\mathrm{R}$ & Solvent & Lewis Ac. & $\mathbf{7 : 8 : 9}$ & Yield $(\%)^{\mathrm{b}}$ \\
\hline 1 & $\mathrm{Cbz}$ & $\mathrm{CH}_{2} \mathrm{Cl}_{2}$ & $\mathrm{TMSOTf}^{\mathrm{a}}$ & $2: 1: 0$ & 85 \\
2 & $\mathrm{Cbz}$ & $\mathrm{CH}_{2} \mathrm{Cl}_{2}$ & $\mathrm{TiCl}_{4}$ & $1.2: 1: 0$ & 70 \\
3 & $\mathrm{Cbz}$ & $\mathrm{CH}_{2} \mathrm{Cl}_{2}$ & $\mathrm{BF}_{3} . \mathrm{OEt}_{2}$ & $1.2: 1: 0$ & 50 \\
4 & $\mathrm{Cbz}$ & $\mathrm{Et}_{2} \mathrm{O}$ & $\mathrm{TMSOTf}^{2}$ & $1.1: 1: 0$ & 65 \\
5 & $\mathrm{Cbz}$ & $\mathrm{Et}_{2} \mathrm{O}$ & $\mathrm{TiCl}_{4}$ & $1.2: 1: 0$ & 58 \\
6 & $\mathrm{Cbz}$ & $\mathrm{Et}_{2} \mathrm{O}$ & $\mathrm{BF}_{3} . \mathrm{OEt}_{2}$ & $1.1: 1: 0$ & 50 \\
7 & $\mathrm{Cbz}$ & $\mathrm{THF}$ & $\mathrm{TMSOTf}^{2}$ & $1.3: 1: 0$ & 55 \\
8 & $\mathrm{Cbz}$ & $\mathrm{THF}$ & $\mathrm{TiCl}_{4}$ & - & - \\
9 & $\mathrm{Cbz}$ & $\mathrm{THF}$ & $\mathrm{BF}_{3} . \mathrm{OEt}_{2}$ & $1.1: 1: 0$ & 42 \\
10 & $\mathrm{Cbz}$ & $\mathrm{THF} / \mathrm{CH}_{2} \mathrm{Cl}_{2}$ & $\mathrm{TMSOTf}^{2}$ & $6: 1: 0$ & 80 \\
11 & $\mathrm{Cbz}$ & $\mathrm{THF} / \mathrm{CH}_{2} \mathrm{Cl}_{2}$ & $\mathrm{TiCl}_{4}$ & - & - \\
12 & $\mathrm{Cbz}$ & $\mathrm{THF} / \mathrm{CH}_{2} \mathrm{Cl}_{2}$ & $\mathrm{BF}_{3} . \mathrm{OEt}_{2}$ & $1.4: 1: 0$ & 43 \\
13 & $\mathrm{Boc}$ & $\mathrm{THF} / \mathrm{CH}_{2} \mathrm{Cl}_{2}$ & $\mathrm{TMSOTf}_{1}$ & $18.5: 1: 11$ & 67 \\
14 & $\mathrm{Boc}$ & $\mathrm{THF} / \mathrm{CH}_{2} \mathrm{Cl}_{2}$ & $\mathrm{TiCl}_{4}$ & - & - \\
15 & $\mathrm{Boc}$ & $\mathrm{THF} / \mathrm{CH}_{2} \mathrm{Cl}_{2}$ & $\mathrm{BF}_{3} . \mathrm{OEt}_{2}$ & $15: 1: 9.8$ & 40 \\
\hline
\end{tabular}

${ }^{a}$ Diastereoisomeric ratio determined by $\mathrm{GC}$ and confirmed by ${ }^{1} \mathrm{H}-$ NMR analyses; ${ }^{b}$ Yields determined after column chromatography on silica gel of the crude product. due to increased steric hindrance involving the methyl group at C-5 in silyloxyfuran $\mathbf{5}$ and the $N$-Boc group (Table 1).

The relative configuration at the two newly generated stereogenic centers was established after catalytic hydrogenation of $\mathbf{7 a}, \mathbf{b}$ and $\mathbf{8 a}, \mathbf{b}$, followed by methanolysis, to give quinolizidinones $\mathbf{1 2}$ and $\mathbf{1 3}$, as illustrated below for 7a and 8a (Scheme 1). Comparison of the nOe experiments performed with quinolizidinones 12 (no increment on $\mathrm{H}-9 \mathrm{a}$ upon irradiation of the methyl group at $\mathrm{C}-1)$ and $\mathbf{1 3}$ (3.4\% increment of the signal of $\mathrm{H}-9 \mathrm{a}$ upon
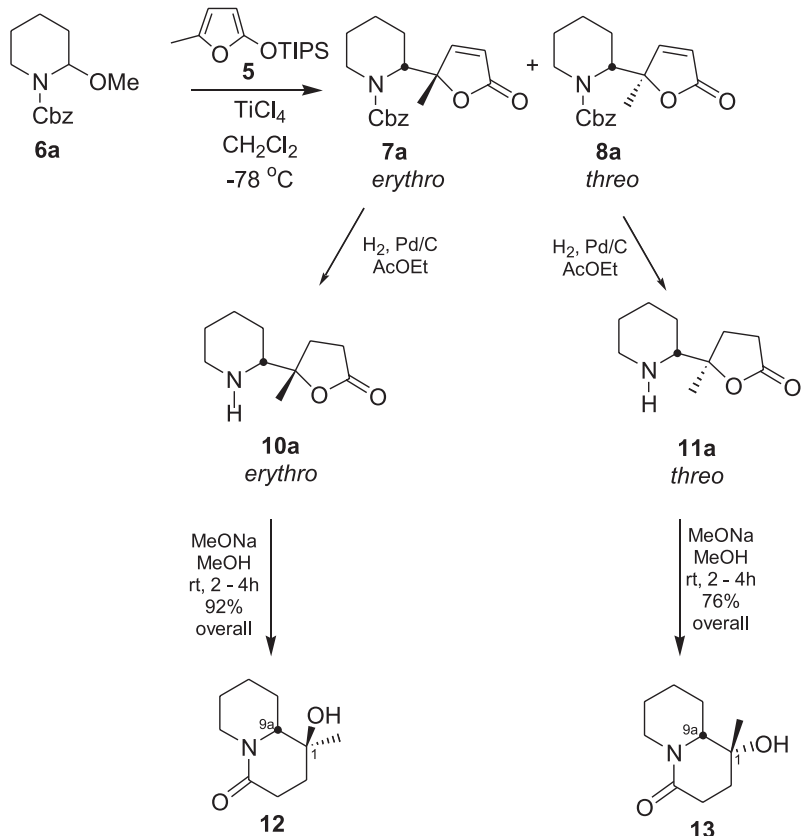

Scheme 1. Conversion of butenolides $7 \mathbf{a}$ and $8 \mathbf{a}$ to the corresponding quinolizidinones $\mathbf{1 2}$ and $\mathbf{1 3}$. 
irradiation of the methyl group at C-1) allowed us to establish the erythro relative configuration for the major diastereoisomer $7 \mathbf{a}$ formed in the coupling reaction of $\mathbf{6 a}$ and silyloxyfuran $\mathbf{5}$.

The stereochemical outcome of the above reaction came to us as a surprise as previous results from our laboratory ${ }^{8}$ and elsewhere ${ }^{5}$ with 1-silyloxyfurans led us to predict the preferential formation of the threo isomer. Additionally, theoretical calculations of the transition state geometries associated with the addition of 5-methylsilyloxyfuran $\mathbf{5}$ to the $N$-acyliminium ion precursors at DFT level (B3LYP/3$21 \mathrm{G}^{*}$ ) showed that array A (relative energy: $1.52 \mathrm{kcal} \mathrm{mol}^{-1}$ ) displaying an antiperiplanar approach of the $\pi$ systems of the nucleophile and $N$-acyliminium ion leads to the lowest energy transition state for the erythro isomer while array $\mathbf{E}$ (relative energy: $0 \mathrm{kcal} \mathrm{mol}^{-1}$ ) with a synclinal arrangement is prefered for the transition state leading to the threo isomer. Martin and coworkers have found a similar result for the transition state calculations $\left(\mathrm{RHF} / 3-21 \mathrm{G}^{*}\right)$ in the addition of 2-methoxyfuran to 5-membered $\mathrm{N}$-carbomethoxy- $\mathrm{N}$ acyliminium ion. ${ }^{7}$ Although at this point, we are not able to rationalize the reversal of the stereochemical outcome observed when 5-methyl-2-silyloxyfuran 5 was employed, the unexpected preference for the erythro isomer may be due to the steric hindrance posed by the methyl group at $\mathrm{C}$ 5 which has not being properly taken into account in the DFT calculations.

The addition of 5-methylsilyloxyfuran 5 to the $\mathrm{N}$ acyliminium ion derived from chiral 2-methoxypiperidine carbamate $\mathbf{6 c}$ (Scheme 2) afforded butenolide 7c as the major diastereoisomer (diastereoisomeric ratio 12:1 determined by capillary GC analysis). Surprisingly, the regioisomer 9 c (relative configuration not determined) was formed upon changing the order of addition of the reagents: whereas none of regioisomer 9c was observed when $\mathrm{TiCl}_{4}$ was added to a solution of methoxycarbamate $\mathbf{6 c}$ in dichloromethane, followed by the addition of silyloxyfuran 5, significant amounts were formed when
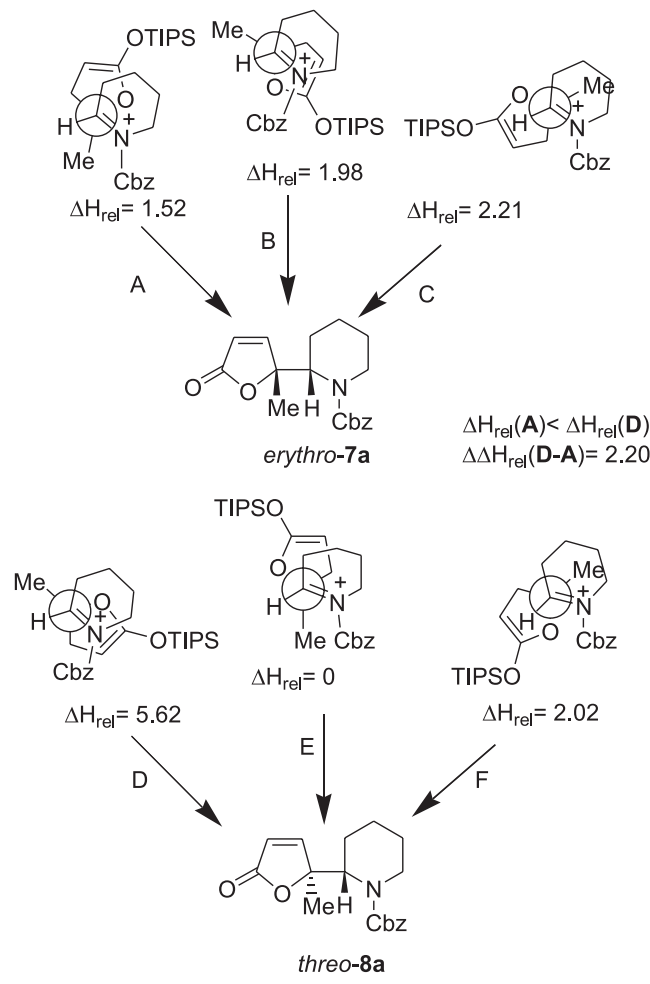

Figure 4. Transition state models for the formation of erythro-7a and threo-8a.

the Lewis acid was added to a mixture of $\mathbf{6 c}$ and $\mathbf{5 .}$

The relative configuration at the two newly generated stereogenic centers was established after catalytic hydrogenation to $\mathbf{1 0 c}$, followed by methanolysis to give quinolizidinone $\mathbf{1 2}$ and the recovery of the chiral auxiliary. However, the absolute configuration has not being unambiguously established yet. The $\mathrm{Si}$-face selectivity of the chiral $N$-acyliminium ion derived from $\mathbf{6} \mathbf{c}$ was proposed based on our previous results with 8-phenylmenthyl chiral auxiliaries ${ }^{8}$ and was rationalized through the kinetically preferred attack of the nucleophile to the s-cis conformation of $\mathrm{N}$-acyliminium ions (Scheme 2), ${ }^{9}$ that might be enforced by $\pi$-stacking interactions ${ }^{10}$ involving

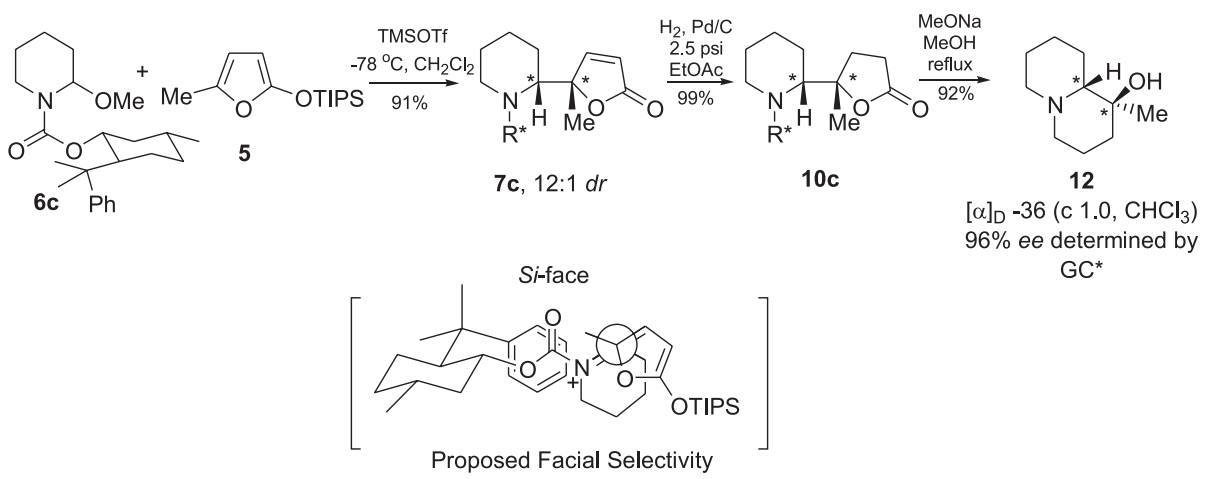

Scheme 2. Proposed facial discrimination in the addition of $\mathbf{5}$ to the $N$-acyliminium ion derived from 2 -methoxycarbamate $\mathbf{6 c}$ (*the absolute configuration may be the opposite as shown). 
the low-lying LUMO of the carbamoyl group and HOMO of the phenyl substituent.

Assembly of quinolizidinone 13, the requisite precursor for the preparation of homopumiliotoxin 223G (1), was achieved from butenolide $\mathbf{8 a}$ in $76 \%$ overall yield (Scheme 1) which was best prepared through the reaction of 2methoxycarbamate 6a and 2-triisopropylsilyloxy-5methylfuran (5) in $\mathrm{CH}_{2} \mathrm{Cl}_{2}$ at $-78{ }^{\circ} \mathrm{C}$ promoted by $\mathrm{TiCl}_{4}$ (Table 1, entry 2). Under these conditions, a mixture (1.2:1.0) of butenolides 7a:8a (70\% combined yield) was formed which afforded $\mathbf{8 a}$ in $32 \%$ yield, after separation by column chromatography on silica gel.

The construction of the (Z)-alkylidene side chain and the synthesis of homopumiliotoxin $223 G(\mathbf{1})$

With an access to the heterocyclic core of homopumiliotoxin $223 \mathrm{G}$ secured, we focused on the aldol reaction as the central strategy to install the $(Z)$-alkylidene side chain characteristic of this family of alkaloids. In order to evaluate the stereochemical outcome of the aldol reaction of lithium enolates derived from six-membered lactams, we first examined the addition of the lithium enolate of readily available $N$-ethyl- $\delta$-valerolactam, (prepared in $96 \%$ yield from $\delta$-valerolactam and ethyl iodide) to isobutyraldehyde. The reaction of its lithium enolate (generated in THF at $-78^{\circ} \mathrm{C}$ with LDA or LiHMDS) with isobutyraldehyde afforded two aldol products 14a:14b in 3.9:1 ratio and 75\% yield when LDA was employed and 4.4:1 ratio and 60\% yield with LiHMDS. The determination of diastereoisomeric ratio was achieved by $\mathrm{GC}$ and confirmed by ${ }^{1} \mathrm{H}-\mathrm{NMR}$. The relative configuration of the major diastereoisomer was tentatively assigned at this point as anti-14a based on the magnitude of the coupling constant $(9.2 \mathrm{~Hz})$ between $\mathrm{H}-3$ and $\mathrm{H}-1^{\prime}$ and the relative shielding of C-3 and C-1' ( $\delta 44.0$ and 76.3, respectively) in the major adduct as compared to the minor one ( $\delta 44.8$ and 76.6, respectively). The deshielding of the hydroxylic hydrogen in the ${ }^{1} \mathrm{H}-\mathrm{NMR}$ spectrum of $\mathbf{1 4 a}$ $(\delta$ 5.90) and the lower stretching frequencies of the

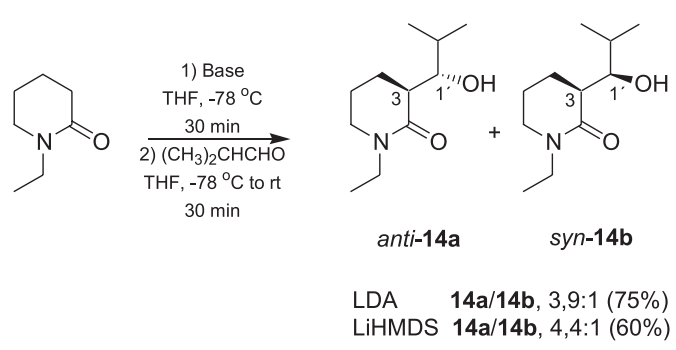

Scheme 3. Aldol reaction of lithium enolate of $N$-ethyl- $\delta$-valerolactam with isobutiraldehyde. hydroxyl and carbonyl groups (3338 and $1610 \mathrm{~cm}^{-1}$, respectively) in 14a as compared to $\mathbf{1 4 b}$ (3423 and 1622 $\mathrm{cm}^{-1}$, respectively) are consistent with a hydrogen-bonded hydroxyl group in $\mathbf{1 4 a}$.

The relative stereochemistry was eventually established after syn elimination carried out under the conditions described by Corey and coworkers. ${ }^{11}$ Treatment of the major diastereoisomer 14a with dicyclohexylcarbodiimide (DCC) and cuprous chloride in refluxing toluene stereospecifically provided $(E)$-isobutylidene piperidinone 15a in $88 \%$ yield, while under the same conditions (Z)-isobutylidene piperidinone $\mathbf{1 5 b}$ was formed in $87 \%$ yield from the minor aldol adduct $\mathbf{1 4 b}$.

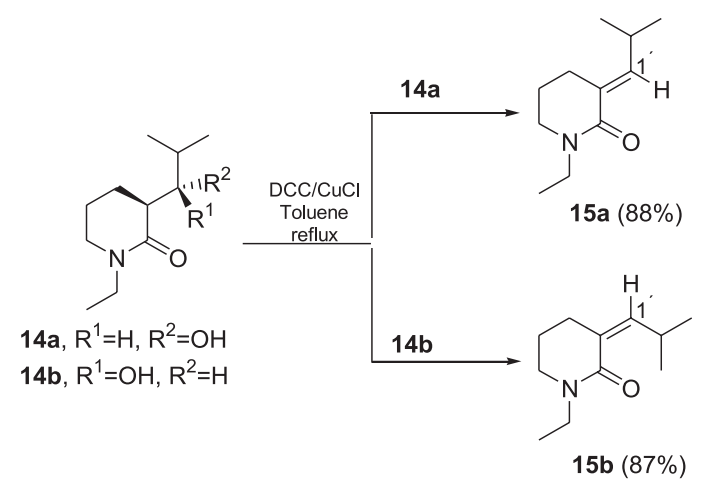

Scheme 4. Model studies of syn elimination with 14a and 14b.

The relative configuration of the isobutylidene piperidinones 15a and $\mathbf{1 5 b}$ could be straigthforwardly assigned by inspection of the corresponding ${ }^{1} \mathrm{H}-\mathrm{NMR}$ spectra, particularly from the H-1' signal which appeared deshielded in 15a $(\delta 6.65)$ in comparison with $\mathbf{1 5 b}(\delta 5.49)$ as the result of the anisotropic effect of the carbonyl group.

Next we evaluated the reaction of the preformed lithium enolate of quinolizidinone $\mathbf{1 3}$ with isobutyraldehyde which produced a 20:1 mixture of two aldol adducts 16a:16b in $85 \%$ yield, as depicted in Scheme 5. Only two out of the four possible stereoisomers were formed. The syn and anti stereochemistries were assigned by analogy to the above results. Moreover, an outstanding selectivity was observed: the diastereoisomeric ratio was determined by GC and ${ }^{1} \mathrm{H}-\mathrm{NMR}$ to be 20:1 and 32:1 for the lithiumand titanium (IV)-mediated reactions, respectively.

The relative configuration of the two newly created stereogenic centers was unequivocally established after syn elimination to the corresponding isobutylidene derivatives. Treatment of the major aldol product anti16a with DCC and cuprous chloride in refluxing toluene afforded $(E)-\mathbf{1 7}$ in $\mathbf{9 5 \%}$ yield while $(Z)-\mathbf{1 7}$ was formed in 95\% yield from the minor aldol adduct syn-16b. The assignment of the configuration of the double bond was 


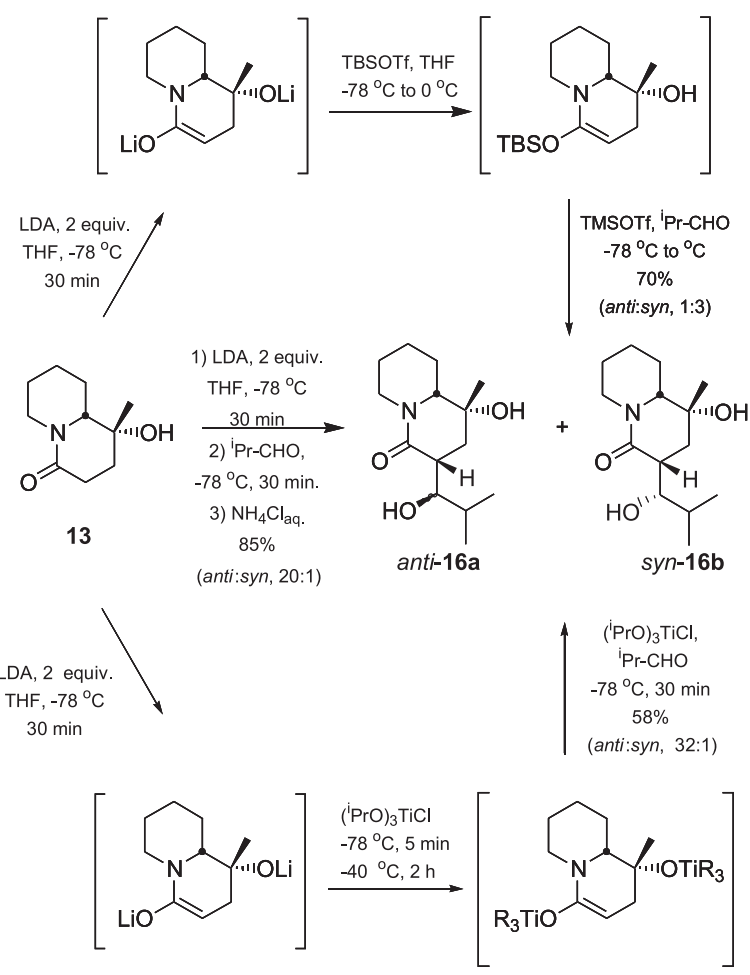

Scheme 5. Aldol reaction of lithium, titanium(IV) and silicon enolates of 13 with isobutyraldehyde.

possible upon inspection of the ${ }^{1} \mathrm{H}-\mathrm{NMR}$ spectra which displayed H-1' deshielded in $(E)-17(\delta$ 6.81) when compared to $(Z)-\mathbf{1 8}(\delta$ 5.60). Alternatively, Mukaiyama aldol reaction of the $\mathrm{N}, \mathrm{O}$-silylketene acetal derived from $\mathbf{1 3}^{12}$ let to a reversal in the stereochemical outcome and aldol syn-16b was formed as the major isomer (3:1 mixture of syn-16b:anti-16a) in 70\% yield, Scheme 5 .

The high diastereoselection observed in the aldol reactions with lithium and titanium (IV) enolates led us to consider that these metal enolates provided highly selective aldol reaction under chelation control according to a Zimmerman-Traxler model (Scheme 7). The formation of diastereoisomers anti-16a and syn-16b was accounted for based on the approach of the aldehyde cis to the lithiated hydroxyl group of quinolizidinone $\mathbf{1 3}$.

Thus, the relative stereochemistry of the aldol adduct lactam at C-3 and C1' was generated by the attack of the enolates into the aldehyde through its concave face. These results could be rationalized by the preformed quaternary lithium alkoxide in the enolate formation step, stabilizing the quinolizidinone enolate through a possible lithium dimer interaction, affording anti-16a preferentially due to the relief of the steric hindrance involving the isopropyl group which is axially positioned in the transition state model leading to syn-16b (Scheme 7). Theoretical analysis through geometry optimization of the possible conformers of anti-16a using DFT method (B3LYP/STO-3G, Gaussian98 program), ${ }^{13}$ as well as the semi empiric methods PM3 and AM1, showed an increase in the stability ranging from 1.8 to $4 \mathrm{kcal} / \mathrm{mol}$ when a hydrogen bond involving the carbonyl and hydroxyl groups is present. Additionally, geometry optimization using semi-empirical and $a b$ initio

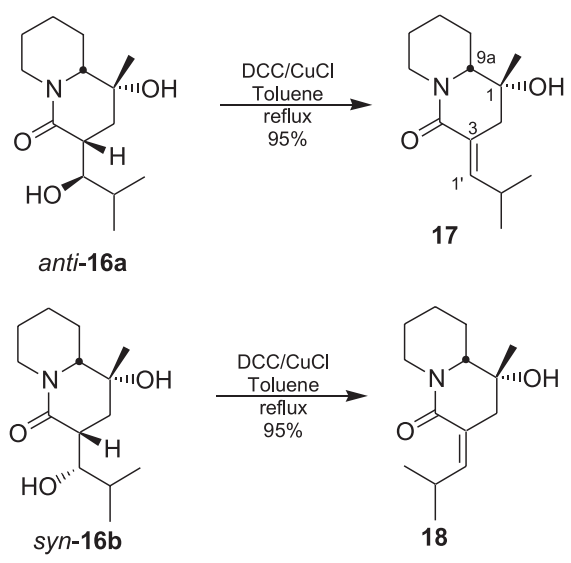
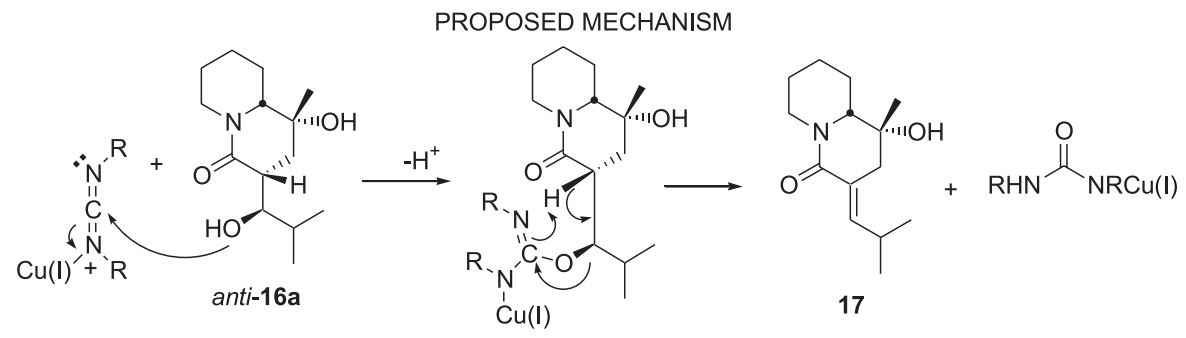


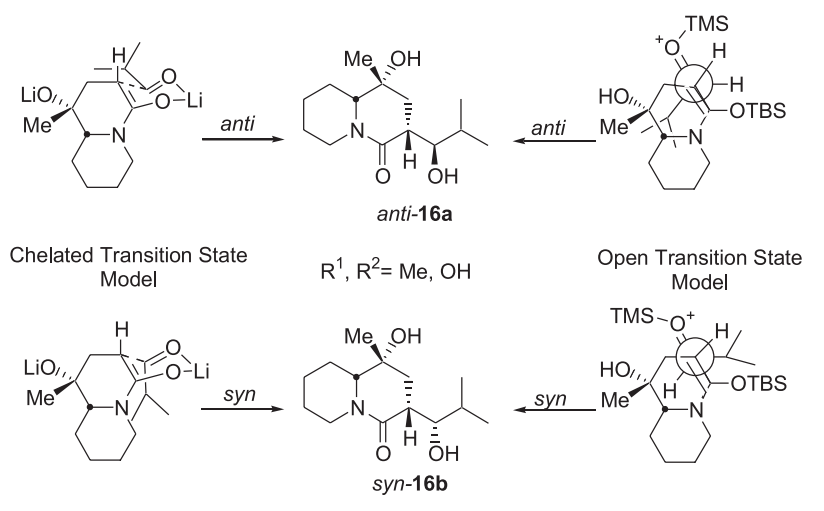

Scheme 7. Zimmerman-Traxler and Mukaiyama transition state models for aldol reactions with quinolizidinone $\mathbf{1 3}$.

(DFT) methods showed that anti-16a is more stable by 0.39 (using PM3), 2.18 (using AM1) and $8.39 \mathrm{kcal} \mathrm{mol}^{-1}$ (using DFT) than its corresponding epimer at C-3 and C-1' which would require cis approach of the aldehyde to the methyl group at the quaternary center through a Zimmerman-Traxler transition state.

The preferential formation of syn-16b when the N,Osilylketeneacetal from quinolizidinone $\mathbf{1 3}$ was employed (Mukaiyama conditions) may be rationalized through a preferential open transition state model with antiperiplanar approach of the $\mathrm{N}, \mathrm{O}$-silylketeneacetal to the aldehyde so as to relieve the steric strain between the isopropyl group of the aldehyde and the quinozilidine ring (Scheme 7).

At this point, we needed to secure an efficient and stereospecific anti elimination methodology in order to benefit from the highly stereoselective formation of anti16a when the lithium or titanium(IV) enolates were employed (Scheme 5) and we that goal in mind several reaction conditions were investigated.

Initially, we employed anti-14a as our model compound and the results are summarized in Scheme 8. The conversion of anti-14a to the corresponding mesylate 19, followed by elimination in refluxing pyridine provided only (E)-15a. The same stereochemical outcome was observed by Gallagher ${ }^{16}\left(1 . \mathrm{Me}_{2} \mathrm{SO}_{2} \mathrm{Cl}\right.$, py, $0{ }^{\circ} \mathrm{C}$ to $\mathrm{rt} ; 2$. $\mathrm{HCl}$; 3. $\mathrm{MeOH} / \mathrm{KOH}$, reflux) (Scheme 8, equation 2). Reasoning that the preferential formation of $(E)-\mathbf{1 5 a}$ resulted from a competitive ElcB mechanism which would be enforced over the expected E2 by polar solvents, we decided to investigate elimination of $\mathbf{1 9}$ in hexane with DBU as base. Compared to bases such as pyridine, this amidine base (DBU) is particularly effective in promoting elimination reactions. ${ }^{14}$ In fact, under these conditions a 3:1 mixture of stereoisomers 15a:15b was formed in $88 \%$ yield (Scheme 8, equation 3).The exclusive formation of

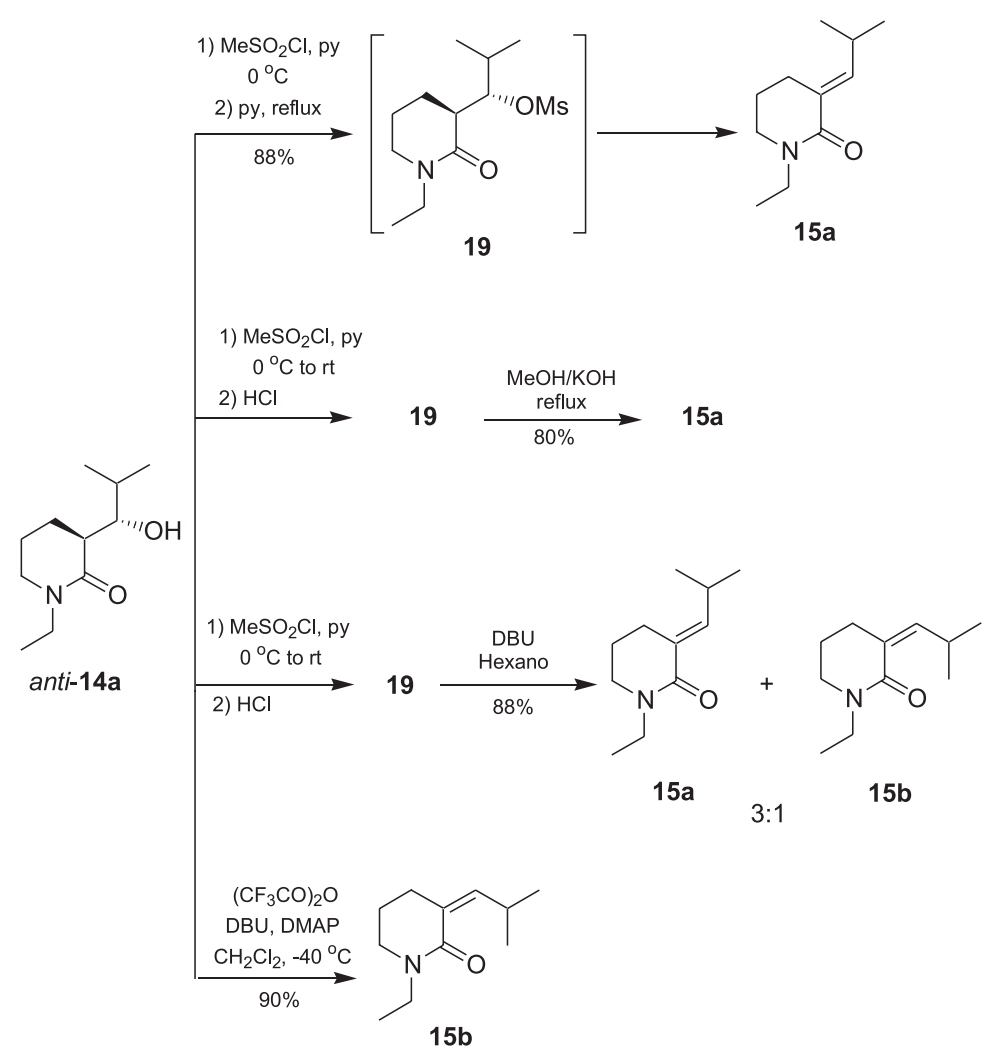


stereoisomer 15b was eventually achieved using Stork protocol, ${ }^{15}$ suggesting that only E2 mechanism was operative under these experimental conditions (Scheme 8, equation 4).

The preference for the formation of $(E)$-isobutylidene side chain was also observed when anti-16a was submitted to the conditions described by Gallagher et al. ${ }^{16}$ which provided $(E)-\mathbf{1 7}$ in $\mathbf{8 3 \%}$ yield. However, as observed above for anti-14a, under Stork conditions only the desired $(Z)$ isomer $\mathbf{1 8}$ was formed in $80 \%$ yield (Scheme 9).

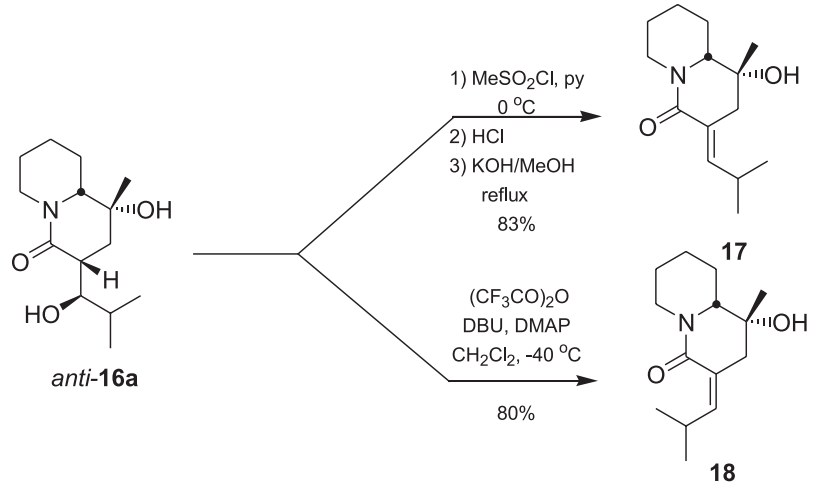

Scheme 9. Stereospecific elimination from anti-16a.

(Z)-Alkylidenelactam 18 was then reduced with alane and after acidification with methanolic $\mathrm{HCl}$, homopumiliotoxin $223 \mathrm{G}$ (1) was isolated as the corresponding hydrochloride salt in $82 \%$ yield (Scheme 10).
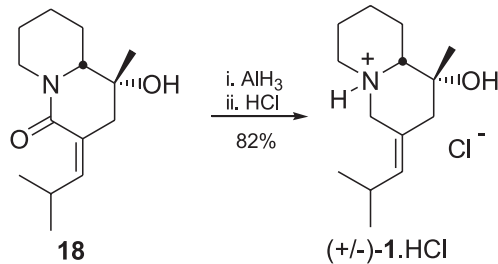

Scheme 10. Conversion of $\mathbf{1 8}$ to (+/-)-homopumiliotoxin $223 \mathrm{G}$ (1) $\mathrm{HCl}$.

The vinylogous Michael addition of silyloxyfuran $\mathbf{5}$ to $\alpha$-methoxycarbamate $\mathbf{6 a}$ was employed in the total synthesis of ( \pm )-homopumiliotoxin 223G (1) alkaloid which was accomplished in 5 steps and $13 \%$ overall yield. The approach may find good use also in the preparation of indolizidine alkaloids and provide a good solution to the installation of the (Z)-alkylidene side chain in heterocyclic systems. Additionally, our initial results on the asymmetric version of the vinylogous Mannich reaction employing chiral carbamate $\mathbf{6 c}$ may be considered for the preparation of the asymmetric version by the route described above.

\section{Experimental}

\section{General}

All experiments were carried out under an argon atmosphere except for hydrolysis under acid conditions. Dichloromethane was distilled from $\mathrm{CaH}_{2}$, tetrahydrofuran previously treated with $\mathrm{CaH}_{2}$ and distilled from sodium, methanol was distilled from $\mathrm{Mg}$ tunnings. The normal extracts consisted of drying over $\mathrm{MgSO}_{4}$, filtration and concentration under reduced pressure with a rotatory evaporator. The compounds were purified by column chromatography on silica gel (70-230 mesh). The ${ }^{1} \mathrm{H}-\mathrm{NMR}$ and ${ }^{13} \mathrm{C}$-NMR spectra were recorded on a Varian Gemini (7.05T), Varian Inova (11.7T) spectrometers. Chemical shifts $(\delta)$ are recorded in ppm with the solvent resonance as the internal standard and coupling constants $(J)$ recorded in Hz. Signals for rotational and/or configuration isomers are denoted inside brackets. The infrared spectra were recorded as films in $\mathrm{KBr}$ cells on a Nicolet Impact 410 (FTIR). High resolution mass spectroscopy (HRMS) were performed on a Autoespec-Micromass-EBE. Optical rotations were measured on a polarimeter Polamat A Carl Zeiss Jena using a quartz cell and a mercury or sodium lamp. The melting points were measured on an Eletrothermal 9100 apparatus. The gas chromatography analyses (FID detector) were performed using a HP-5890II equipament. Gas chromatography-mass spectrometry (GC-MS) analyses were performed on a Hewlett Packard 5890/ Hewlett Packard 5970 MSD.

Benzyl (2R*)-2-[(2S*)-2-methyl-5-oxo-2,5-dihydro-2furanyl]hexahydro-1-pyridinecarboxylate (7a) and benzyl (2R*)-2-[(2R*)-2-methyl-5-oxo-2,5-dihydro-2furanyl]hexahydro-1-pyridinecarboxylate (8a)

To a solution of metoxycarbamate $\mathbf{6 a}^{18}(0.18 \mathrm{mmol}$ $0.045 \mathrm{~g})$ in anhydrous $\mathrm{CH}_{2} \mathrm{Cl}_{2}(1.00 \mathrm{~mL})$ at $-78{ }^{\circ} \mathrm{C}$ was added $\mathrm{TiCl}_{4}(0.18 \mathrm{mmol}, 0.020 \mathrm{~mL})$ and the black mixture was stirred for $30 \mathrm{~min}$. under argon atmosphere, followed by slow addition of 2-(5-methyl)-triisopropylsilyloxyfuran $5^{19}$ (0.18 mmol, $0.046 \mathrm{~g})$ in $\mathrm{CH}_{2} \mathrm{Cl}_{2}(0.10 \mathrm{~mL})$. After $30 \mathrm{~min}$ saturated aqueous $\mathrm{NH}_{4} \mathrm{Cl}(1.00 \mathrm{~mL})$ was added and the layers were separated. The aqueous phase was extracted with $\mathrm{CH}_{2} \mathrm{Cl}_{2}(2 \times 5 \mathrm{~mL})$, and the combined organic phase was dried over $\mathrm{MgSO}_{4}$ and concentrated under reduced pressure. The crude was submitted to flash column chromatography purification (hexane/ethyl acetate, $2: 1)$ affording 7a $(0.022$ $\mathrm{g}, 0.069 \mathrm{mmol})$ and $8 \mathbf{a}(0.018 \mathrm{~g}, 0.057 \mathrm{mmol})$ in a $1.2: 1$ diastereoisomeric mixture, in $70 \%$ combined yield. $7 a .{ }^{1} \mathrm{H}-$ $\mathrm{RMN}\left(500 \mathrm{MHz}, \mathrm{CDCl}_{3}\right) \delta 1.20-1.26(1 \mathrm{H}, \mathrm{m}), 1.43$ (3H, s), 
1.45-1.60 (2H, m), 1.68-1.88 (3H, m), 3.14-3.26 (1H, m), $4.14(0.75 \mathrm{H}, \mathrm{bd}, J 11.7 \mathrm{~Hz}), 4.25(0.25 \mathrm{H}, \mathrm{bd}, J 11.7 \mathrm{~Hz})$, $4.38(0.44 \mathrm{H}, \mathrm{m}), 4.55(0.56 \mathrm{H}, \mathrm{d}, J 6.1 \mathrm{~Hz}), 5.04-5.22(2 \mathrm{H}, \mathrm{m}$, $J 3.7 \mathrm{~Hz}), 6.10$ (1H, bd, J 5.6 Hz), 7.29-7.40 (5H, m), 7.42 $(1 \mathrm{H}$, bd, $J 5.6 \mathrm{~Hz}) .{ }^{13} \mathrm{C}-\mathrm{RMN}\left(125 \mathrm{MHz}, \mathrm{CDCl}_{3}\right) \delta: 20.4$ $\left(\mathrm{CH}_{2}\right), 21.6(\mathrm{CH} 3), 23.6\left(\mathrm{CH}_{2}\right), 24.9\left(\mathrm{CH}_{2}\right), 40.0\left(\mathrm{CH}_{2}\right), 53.7$ $(\mathrm{CH}), 67.5\left(\mathrm{CH}_{2}\right), 93.2(\mathrm{C}), 121.0(\mathrm{CH}), 127.7(2 \mathrm{xCH}), 128.1$ $(\mathrm{CH}), 128.5(2 \times \mathrm{CH}), 136.8(\mathrm{C}), 159.8(\mathrm{C}), 160.2(\mathrm{CH}), 172.5$ (C). IR ( $\mathrm{NaCl}$ film) $v_{\max } / \mathrm{cm}^{-1}: 1765,1689$. GC-MS (EI) $\mathrm{m} / \mathrm{z}$ : 218(8\%), 174(23\%), 91(100\%). 8a. ${ }^{1} \mathrm{H}-\mathrm{RMN}(500 \mathrm{MHz}$, $\left.\mathrm{CDCl}_{3}\right) \delta: 1.19-2.11(6 \mathrm{H}, \mathrm{m}), 1.41(3 \mathrm{H}, \mathrm{s}), 2.82(1 \mathrm{H}, \mathrm{m}), 3.91$ $(1 \mathrm{H}, \mathrm{dd}, J 12.9,3.9 \mathrm{~Hz}), 4.98(1 \mathrm{H}, \mathrm{d}, J 2.0 \mathrm{~Hz}), 5.02(2 \mathrm{H}, \mathrm{dd}$, $J$ 15.1, $12.0 \mathrm{~Hz}), 5.74(1 \mathrm{H}, \mathrm{d}, J 5.1 \mathrm{~Hz}), 7.20-7.30(5 \mathrm{H}, \mathrm{m})$, $7.43(1 \mathrm{H}, \mathrm{d}, J 5.1 \mathrm{~Hz}) .{ }^{13} \mathrm{C}-\mathrm{RMN}\left(125 \mathrm{MHz}, \mathrm{CDCl}_{3}\right) \delta: 19.4$ $\left(\mathrm{CH}_{2}\right), 22.2(\mathrm{CH} 3), 23.6\left(\mathrm{CH}_{2}\right), 24.3\left(\mathrm{CH}_{2}\right), 41.1\left(\mathrm{CH}_{2}\right), 54.9$ $(\mathrm{CH}), 67.5\left(\mathrm{CH}_{2}\right), 93.4(\mathrm{C}), 119.4(\mathrm{CH}), 127.9(2 \times \mathrm{CH}), 128.3$ (CH), $128.7(2 \times C H), 136.8(\mathrm{C}), 156.3(\mathrm{C}), 160.8(\mathrm{CH}), 173.1$ (C). IR ( $\mathrm{NaCl}$ film) $v_{\max } / \mathrm{cm}^{-1}: 2949,1765,1697$. GC-MS (EI) $\mathrm{m} / \mathrm{z}: 218(8 \%), 174(23 \%), 91(100 \%)$.

tert-Butyl $\left(2 R^{*}\right)$-2-[(2R*)-2-methyl-5-oxo-2,5-dihydro-2furanyl]hexahydro-1-pyridinecarboxylate ( $7 \boldsymbol{b})$

IR $(\mathrm{KBr}) v_{\max } / \mathrm{cm}^{-1}: 3365,3086,3064,2976,2937$, 2871, 1768, 1689, 1452, 1414, 1369, 1275, 1250, 1152, 1034, 957, 822, 768. ${ }^{1} \mathrm{H}-\mathrm{RMN}\left(300 \mathrm{MHz}, \mathrm{CDCl}_{3}\right) \delta 1.41$ $(3 \mathrm{H}, \mathrm{d}, J 2.5 \mathrm{~Hz}), 1.46$ (9H, s), 1.24-1.53 (4H, m), 1.52-1.67 $(1.8 \mathrm{H}, \mathrm{m}), 1.98(0.2 \mathrm{H}, \mathrm{dt}, J 1.5,7.0 \mathrm{~Hz}), 2.70-3.12(1 \mathrm{H}, \mathrm{m})$, 3.48-3.88 (0.2H, m), 3.99 (0.6H, bd, J 13.6 Hz), 4.09-4.13 $(0.2 \mathrm{H}, \mathrm{m}), 4.31(0.4 \mathrm{H}, \mathrm{m}), 4.50(0.6 \mathrm{H}, \mathrm{m}), 6.07(1 \mathrm{H}, \mathrm{d}, J 5.5$ $\mathrm{Hz}), 7.39(1 \mathrm{H}, \mathrm{d}, J 5.5 \mathrm{~Hz}) .{ }^{13} \mathrm{C}-\mathrm{RMN}\left(75 \mathrm{MHz}, \mathrm{CDCl}_{3}\right) \delta$ : $20.5\left(\mathrm{CH}_{2}\right), 24.0\left(\mathrm{CH}_{3}\right), 24.9\left(\mathrm{CH}_{2}\right), 28.3\left(\mathrm{CH}_{2}\right), 28.3$ $\left(3 \mathrm{XCH}_{3}\right), 40.9\left(\mathrm{CH}_{2}\right), 52.7(\mathrm{CH}), 79.9(\mathrm{C}), 93.4(\mathrm{C}), 120.9$ $(\mathrm{CH}), 160.4(\mathrm{C}), 160.8(\mathrm{CH}), 172.2(\mathrm{C})$. HRMS (EI): found 224.0924; calc. for $\mathrm{C}_{11} \mathrm{H}_{14} \mathrm{NO}_{4}\left(\mathrm{M}^{+*}-{ }^{\mathrm{H}} \mathrm{Bu}\right)$ : 224.0923.

tert-Butyl 2-(5-methyl-2-oxo-2,3-dihydro-3-furanyl)-1piperidinecarboxylate $(\mathbf{9 b})$

$\mathrm{IR}(\mathrm{KBr}) v_{\max } / \mathrm{cm}^{-1}: 3105,2974,2937,2864,1795,1697$, $1452,1412,1367,1162 .{ }^{1} \mathrm{H}-\mathrm{RMN}\left(300 \mathrm{MHz}, \mathrm{CDCl}_{3}\right) \delta 1.34-$ $1.38(9 \mathrm{H}, \mathrm{m}), 1.48-1.59(5 \mathrm{H}, \mathrm{m}), 1,70(0.5 \mathrm{H}, \mathrm{m}), 1,89(0.9 \mathrm{H}$, d, $J 1.5 \mathrm{~Hz}), 1.90(0.9 \mathrm{H}, \mathrm{d}, J 1.5 \mathrm{~Hz}), 1.91(0.6 \mathrm{H}, \mathrm{d}, J 1.5 \mathrm{~Hz})$, $1.92(0.6 \mathrm{H}, \mathrm{d}, J 1.5 \mathrm{~Hz}), 2.19(0.5 \mathrm{H}, \mathrm{bd}, J 9.2 \mathrm{~Hz}), 2.66(1 \mathrm{H}$, m), $3.46(0.3 \mathrm{H}, \mathrm{dt}, J 1.5,7.7 \mathrm{~Hz}), 3.58(0.7 \mathrm{H}, \mathrm{dt}, J 2.2,7.7$ $\mathrm{Hz}), 4.00(1 \mathrm{H}, \mathrm{m}), 4.25(1 \mathrm{H}, \mathrm{m}), 4.88(0.32 \mathrm{H}, \mathrm{s}), 5.01(0.68 \mathrm{H}$, t, $J 1.5 \mathrm{~Hz}) .{ }^{13} \mathrm{C}-\mathrm{RMN}\left(75 \mathrm{MHz}, \mathrm{CDCl}_{3}\right) \delta: 18.7\left(\mathrm{CH}_{3}\right), 18.9$ $\left(\mathrm{CH}_{2}\right), 24.9\left(\mathrm{CH}_{2}\right), 27.1\left(\mathrm{CH}_{2}\right), 28.3\left(3 \mathrm{xCH}_{3}\right), 39.6\left(\mathrm{CH}_{2}\right)$, $44.8(\mathrm{CH}), 52.5(\mathrm{CH}), 80.4(\mathrm{C}), 102.1(\mathrm{CH}), 153.1(\mathrm{C}), 154.6$ (C), 177.5 (C). HRMS (EI): found 224.0921; calcd. for $\mathrm{C}_{11} \mathrm{H}_{14} \mathrm{NO}_{4}\left(\mathrm{M}^{+*}-{ }^{\mathrm{t}} \mathrm{Bu}\right): 224.0923$.
( $1 R, 2 S, 5 R)-5$ - Me thy $1-2$ - ( 1 - me thyl- 1 phenylethyl)cyclohexyl (2R)-2-[(2S)-2-methyl-5-oxo-2,5dihydro-2-furanyl]hexahydro-1-pyridinecarboxylate (7c)

The same procedure described for $\mathbf{7 a}$ was employed, affording $7 \mathbf{c}$ in $91 \%$ yield. $\mathrm{mp} 136.4-137.3{ }^{\circ} \mathrm{C} .[\alpha]_{\mathrm{Hg}}{ }^{25}-20$, $\left(\mathrm{c} 1.0, \mathrm{CHCl}_{3}\right)$. IR (KBr) $v_{\max } / \mathrm{cm}^{-1}: 3086,3057,3016,2959$, 2870, 1768, 1689, 1670, 1601, 1423, 1379, 1338(m), 1263(m), 1161(m), 1034, 957, 926, 822, 760, 700. ${ }^{1} \mathrm{H}-\mathrm{RMN}$ $\left(500 \mathrm{MHz}, \mathrm{CDCl}_{3}\right) \delta 0.81(6 \mathrm{H}, \mathrm{d}, J 6.6 \mathrm{~Hz}), 0.84-0.91(1 \mathrm{H}$, $\mathrm{m}), 1.13(3 \mathrm{H}, \mathrm{t}, J 22.0 \mathrm{~Hz}), 1.37(1 \mathrm{H}, \mathrm{s}), 1.32-1.54(3 \mathrm{H}, \mathrm{m})$, 1.57-1.72 (3H, m), 1.81-1.89 (1H, m), 1.93-2.11 $(3 \mathrm{H}, \mathrm{m})$, 2.52 (1H, dt, $J$ 2.4, $13.7 \mathrm{~Hz}), 2.91-2.98(2 \mathrm{H}, \mathrm{m}), 4.04-4.07$ $(1 \mathrm{H}, \mathrm{m}), 4.37(1 \mathrm{H}, \mathrm{d}, J 5.4 \mathrm{~Hz}), 4.69$ (1H, dddd, J 20.0, 9.0, 3.9, $3.9 \mathrm{~Hz}), 5.98(1 \mathrm{H}, \mathrm{dd}, J 5.6,28.1 \mathrm{~Hz}), 7.03-7.10(1 \mathrm{H}$, m), $7.20(3 \mathrm{H}, \mathrm{bd}, J 5.6 \mathrm{~Hz}), 7.18-7.27(1 \mathrm{H}, \mathrm{m}), 7.32(1 \mathrm{H}, \mathrm{d}$, $J 5.6 \mathrm{~Hz}) .{ }^{13} \mathrm{C}-\mathrm{RMN}\left(125 \mathrm{MHz}, \mathrm{CDCl}_{3}\right) \delta 20.4\left(\mathrm{CH}_{2}\right), 21.6$ $\left(\mathrm{CH}_{3}\right), 21.8\left(\mathrm{CH}_{3}\right), 23.4\left(\mathrm{CH}_{2}\right), 24.5\left(\mathrm{CH}_{2}\right), 24.7\left(\mathrm{CH}_{3}\right), 26.6$ $\left(\mathrm{CH}_{2}\right), 28.1\left(\mathrm{CH}_{3}\right), 31.3(\mathrm{CH}), 34.6\left(\mathrm{CH}_{2}\right), 39.5\left(\mathrm{CH}_{2}\right), 39.8$ (C), $42.1\left(\mathrm{CH}_{2}\right), 50.5(\mathrm{CH}), 53.5(\mathrm{CH}), 75.9(\mathrm{CH}), 93.1(\mathrm{CH})$, $120.8(\mathrm{CH}), 125.0(\mathrm{CH}), 125.0(\mathrm{CH}), 125.1(\mathrm{CH}), 128.0$ $(\mathrm{CH}), 128.1(\mathrm{CH}), 152.1(\mathrm{C}), 155.3(\mathrm{C}), 160.3(\mathrm{CH}), 172.6$ (C). HRMS (EI): found 342.2431; calcd. for $\mathrm{C}_{22} \mathrm{H}_{32} \mathrm{NO}_{2}$ $\left(\mathrm{M}^{+*}-\mathrm{C}_{5} \mathrm{H}_{5} \mathrm{O}_{2}\right): 342.2433$.

( $1 R, 2 S, 5 R)-5-M e t h y l-2$ - ( $1-$ me thy $l-1$ phenylethyl)cyclohexyl 2-(5-methyl-2-oxo-2,3-dihydro-3furanyl)-1-piperidinecarboxylate $(\mathbf{9 c})$

$\mathrm{mp} 136.4-137.3{ }^{\circ} \mathrm{C}$. IR (KBr) $v_{\max } / \mathrm{cm}^{-1}: 3087,3057$, 2943, 2864, 2723, 1795, 1689, 1670, 1460, 1425, 1263, 1171, 1113, 1093, 1030, 939, 881, 850, 764. ${ }^{1} \mathrm{H}-\mathrm{RMN}$ $\left(500 \mathrm{MHz}, \mathrm{CDCl}_{3}\right) \delta 0.77(6 \mathrm{H}, \mathrm{d}, J 6.6 \mathrm{~Hz}), 0.82-0.93(1 \mathrm{H}$, m), $0.96(4 \mathrm{H}, \mathrm{s}), 1.12(1 \mathrm{H}, \mathrm{s}), 1.23(1 \mathrm{H}, \mathrm{d}, J 3.4 \mathrm{~Hz}), 1.31$ $1.39(8 \mathrm{H}, \mathrm{m}), 1.79(0.83 \mathrm{H}, \mathrm{s}), 1.87(2.17 \mathrm{H}, \mathrm{s}), 1.82-1.93$ $(1 \mathrm{H}, \mathrm{m}), 2.17(0.73 \mathrm{H}, \mathrm{bd}, J 13.4 \mathrm{~Hz}), 2.24(0.27 \mathrm{H}, \mathrm{bd}, J$ $13.4 \mathrm{~Hz}), 2.47(0.66 \mathrm{H}, \mathrm{bt}, J 12.7 \mathrm{~Hz}), 2.64(0.34 \mathrm{H}, \mathrm{bt}, J$ $12.7 \mathrm{~Hz}), 3.14(0.87 \mathrm{H}, \mathrm{bd}, J 11.7 \mathrm{~Hz}), 3.34(0.13 \mathrm{H}, \mathrm{m}), 3.52$ $(0.73 \mathrm{H}, \mathrm{bd}, J 10.0 \mathrm{~Hz}), 3.65(0.27 \mathrm{H}, \mathrm{bd}, J 10.0 \mathrm{~Hz}), 3.98$ $(0.04 \mathrm{H}, \mathrm{bd}, J 9.8 \mathrm{~Hz}), 4.12(0.08 \mathrm{H}, \mathrm{bd}, J 9.8 \mathrm{~Hz}), 4.15$ $(0.08 \mathrm{H}$, bdd, $J 4.0,9.8 \mathrm{~Hz}), 4.33(0.80 \mathrm{H}, \mathrm{d}, J 9.8 \mathrm{~Hz}), 4.63-$ $4.68(1 \mathrm{H}, \mathrm{m}), 4.74(0.65 \mathrm{H}, \mathrm{s}), 4.95-4.97(0.35 \mathrm{H}, \mathrm{m}), 7.01-$ $7.07(1 \mathrm{H}, \mathrm{m}), 7.17(2 \mathrm{H}, \mathrm{d}, J 2.9 \mathrm{~Hz}), 7.19(2 \mathrm{H}, \mathrm{d}, J 2.2 \mathrm{~Hz})$. ${ }^{13} \mathrm{C}-\mathrm{RMN}\left(125 \mathrm{MHz}, \mathrm{CDCl}_{3}\right) \delta: 14.1\left(\mathrm{CH}_{3}\right), 17.7\left(\mathrm{CH}_{3}\right)$, $18.7\left(\mathrm{CH}_{3}\right), 21.8\left(\mathrm{CH}_{2}\right), 25.1\left(\mathrm{CH}_{3}\right), 25.4\left(\mathrm{CH}_{2}\right), 26.3\left(\mathrm{CH}_{2}\right)$, $26.8\left(\mathrm{CH}_{2}\right), 31.2(\mathrm{CH}), 34.6\left(\mathrm{CH}_{2}\right), 39.2(\mathrm{CH}), 39.3\left(\mathrm{CH}_{2}\right)$, $39.8(\mathrm{C}), 42.4\left(\mathrm{CH}_{2}\right), 50.5(\mathrm{CH}), 51.9(\mathrm{CH}), 75.6(\mathrm{CH}), 101.8$ $(\mathrm{CH}), 125.0(\mathrm{CH}), 125.3(\mathrm{CH}), 125.4(\mathrm{CH}), 125.7(\mathrm{CH})$, $127.8(\mathrm{CH}), 127.9(\mathrm{C}), 151.8(\mathrm{C}), 154.7$ (C), 177.5 (C). HRMS (EI): found 342.2431; calcd. for $\mathrm{C}_{22} \mathrm{H}_{32} \mathrm{NO}_{2}$ $\left(\mathrm{M}^{+*}-\mathrm{C}_{5} \mathrm{H}_{5} \mathrm{O}_{2}^{*}\right): 342.2433$ 
Benzyl (2R*)-2-[(2S*)-2-methyl-5-oxotetrahydro-2furanyl]hexahydro-1-pyridinecarboxylate (10a)

To a solution of $7 \mathbf{a}(0.019 \mathrm{~g}, 0.060 \mathrm{mmol})$ in ethyl acetate $(0.60 \mathrm{~mL})$ was added $\mathrm{Pd} / \mathrm{C}(10 \%)(0.0019 \mathrm{~g})$ and the mixture was stirred under $\mathrm{H}_{2}(1 \mathrm{~atm})$ for $4 \mathrm{~h}$. The mixture was then filtered through Celite, and the pad was rinsed with EtOAc/MeOH (4:1, $10 \mathrm{~mL})$. The organic layer was concentrated under reduced pressure to furnished pure 10a as a colorless oil in $99 \%$ yield $(0.011 \mathrm{~g}, 0.059 \mathrm{mmol}) .{ }^{1} \mathrm{H}-$ $\mathrm{RMN}\left(300 \mathrm{MHz}, \mathrm{CDCl}_{3}\right) \delta 1.02-1.41(2 \mathrm{H}, \mathrm{m}), 1.30(3 \mathrm{H}, \mathrm{s})$, 1.49-1.57 (2H, m), 1.64-1.70 (1H, m), 1.72-1.84 (1H, m), 2.43-2.60 (5H, m), 2.68 (1H, dd, J 11.4, 2.0 Hz), $3.04(1 \mathrm{H}$, dl, J $1.4 \mathrm{~Hz}) .{ }^{13} \mathrm{C}-\mathrm{RMN}\left(75 \mathrm{MHz}, \mathrm{CDCl}_{3}\right) \delta: 23.7\left(\mathrm{CH}_{3}\right)$, $24.3\left(\mathrm{CH}_{2}\right), 25.5\left(\mathrm{CH}_{2}\right), 26.2\left(\mathrm{CH}_{2}\right), 27.6\left(\mathrm{CH}_{2}\right), 29.0\left(\mathrm{CH}_{2}\right)$, $46.6\left(\mathrm{CH}_{2}\right), 63.0(\mathrm{CH}), 89.0(\mathrm{C}), 176.8(\mathrm{C})$. IR (KBr film) $v_{\max } / \mathrm{cm}^{-1}: 1777$. HRMS (EI): found 183,1656; calcd. for $\mathrm{C}_{10} \mathrm{H}_{17} \mathrm{NO}_{2}\left(\mathrm{M}^{+\bullet}\right): 183.1259$.

( $1 R, 2 S, 5 R)-5$ - Me thyl-2 - ( 1 - m e th y l-1phenylethyl)cyclohexyl (2R)-2-[(2S)-2-methyl-5oxo te tra hydro-2 - furanyl] he x a hydro-1pyridinecarboxylate (10c)

To a solution of $7 \mathbf{c}(0.060 \mathrm{mmol})$ in ethyl acetate $(0.60$ $\mathrm{mL})$ was added $\mathrm{Pd} / \mathrm{C}(10 \%)(0.0019 \mathrm{~g})$ and the mixture was stirred under $\mathrm{H}_{2}$ (2.5 psi) for $4 \mathrm{~h}$. The mixture was then filtered through Celite, and the pad was rinsed with EtOAc/ $\mathrm{MeOH}(4: 1,10 \mathrm{~mL})$. The organic layer was concentrated under reduced pressure to furnished pure 10c as a colorless oil in $99 \%$ yield $(0.059 \mathrm{mmol}) .[\alpha]_{\mathrm{Hg}}{ }^{25}-70,0\left(\mathrm{c} 1.5, \mathrm{CHCl}_{3}\right)$. IR $(\mathrm{KBr}) v_{\max } / \mathrm{cm}^{-1}: 2954,2927,2870,1774,1682,1425$, 1385, 1340, 1261, 1180, 1132, 1034, 978, 945, 762, 702. ${ }^{1} \mathrm{H}-\mathrm{RMN}\left(500 \mathrm{MHz}, \mathrm{CDCl}_{3}\right), \delta 0.81(6 \mathrm{H}, \mathrm{d}, J 5.5 \mathrm{~Hz}), 0.79-$ $1.04(1 \mathrm{H}, \mathrm{m}), 1.13(3 \mathrm{H}, \mathrm{t}, J 5.0 \mathrm{~Hz}), 1.28(3 \mathrm{H}, \mathrm{d}, J 26.0 \mathrm{~Hz})$, 1.11-1.47 (9H, m), 1.49-1.69 (4H, m), 1.71-1.80 (1H, m), 1.82-2.06 (1H, m), 2.10-2.17 (1H, m), $2.41(1 \mathrm{H}, \mathrm{dt}, J 13.7$, $2.4 \mathrm{~Hz}), 2.43-2.61(2 \mathrm{H}, \mathrm{m}), 2.91(1 \mathrm{H}, \mathrm{bd}, J 20.1 \mathrm{~Hz}), 4.04-$ 4.12 (1H, m), 4.66 (1H, dddd, J 20.1, 10.7, 4.15, 3.7 Hz), 7.05-7.08 (1H, m), 7.17-7.25 (4H, m). ${ }^{13} \mathrm{C}-\mathrm{RMN}(125 \mathrm{MHz}$, $\left.\mathrm{CDCl}_{3}\right) \delta 20.2\left(\mathrm{CH}_{2}\right), 21.8\left(2 \mathrm{xCH}_{3}\right), 22.9\left(\mathrm{CH}_{2}\right), 24.0\left(\mathrm{CH}_{3}\right)$, $24.6\left(\mathrm{CH}_{2}\right), 24.9\left(\mathrm{CH}_{3}\right), 26.7\left(\mathrm{CH}_{2}\right), 28.1\left(\mathrm{CH}_{2}\right), 31.3(\mathrm{CH})$, $31.7\left(\mathrm{CH}_{2}\right), 34.7\left(\mathrm{CH}_{2}\right), 39.4\left(\mathrm{CH}_{2}\right), 39.5(\mathrm{C}), 42.1\left(\mathrm{CH}_{2}\right)$, $50.5(\mathrm{CH}), 55.9(\mathrm{CH}), 75.8(\mathrm{CH}), 90.0(\mathrm{C}), 124.5(\mathrm{CH})$, $124.8(\mathrm{CH}), 125.1(\mathrm{CH}), 128.0(\mathrm{CH}), 128.1(\mathrm{CH}), 152.1$ (C), 155.5 (C), 176,8 (C).

Benzyl (2R*)-2-[(2R*)-2-methyl-5-oxotetrahydro-2furanyl]hexahydro-1-pyridinecarboxylate (11a)

The same procedure described for 10a was employed using 8a, affording 11a in $98 \%$ yield. ${ }^{1} \mathrm{H}-\mathrm{RMN}(300 \mathrm{MHz}$, $\left.\mathrm{CDCl}_{3}\right) \delta 1.11-1.29(1 \mathrm{H}, \mathrm{m}), 1.32(3 \mathrm{H}, \mathrm{s}), 1.53-1.57(2 \mathrm{H}$, $\mathrm{m}), 1.79-1.90(2 \mathrm{H}, \mathrm{m}), 2.08-2.18(1 \mathrm{H}, \mathrm{m}), 2.45-2.66(6 \mathrm{H}$, m), $3.08(1 \mathrm{H}, \mathrm{m}) .21 .1\left(\mathrm{CH}_{3}\right), 24.6\left(\mathrm{CH}_{2}\right), 25.7\left(\mathrm{CH}_{2}\right), 26.5$ $\left(\mathrm{CH}_{2}\right), 28.8\left(\mathrm{CH}_{2}\right), 31.1\left(\mathrm{CH}_{2}\right), 46.9\left(\mathrm{CH}_{2}\right), 64.8(\mathrm{CH}), 88.8$ (C), 176.5 (C). IR (KBr film) $v_{\max } / \mathrm{cm}^{-1}: 1770$. HRMS (EI): found 183,1112; calcd. for $\mathrm{C}_{10} \mathrm{H}_{17} \mathrm{NO}_{2}\left(\mathrm{M}^{+\bullet}\right)$ : 183.1259 .

(1S*,9aR*)-1-Hydroxy-1-methylperhydro-4-quinolizinone(12)

A solution of $\mathrm{MeONa} / \mathrm{MeOH}\left(1.1 \mathrm{~mol} \mathrm{~L}^{-1}, 2.7 \mathrm{~mL}\right)$ was added to $10 \mathrm{a}(0.083 \mathrm{~g}, 0.45 \mathrm{mmol})$ at $0{ }^{\circ} \mathrm{C}$, and the mixture was stirred at room temperature. After $2 \mathrm{~h}, 1.0 \mathrm{~mL}$ of $\mathrm{HCl} /$ $\mathrm{MeOH}$ solution $\left(2 \mathrm{~mol} \mathrm{~L}^{-1}\right)$ was carefully added. The organic layer was concentrated under reduced pressure, providing 12 in $93 \%$ yield as a white solid $(0.077 \mathrm{~g}, 0.42$ mmol). mp 133.2-134.3 ${ }^{\circ} \mathrm{C} .{ }^{1} \mathrm{H}-\mathrm{RMN}\left(500 \mathrm{MHz}, \mathrm{CDCl}_{3}\right.$ ), $\delta 1.14(1 \mathrm{H}, \mathrm{dq}, J 12.5,3.9 \mathrm{~Hz}), 1.20(3 \mathrm{H}, \mathrm{s}), 1.36(1 \mathrm{H}, \mathrm{dt}$, $J 12.7,3.9 \mathrm{~Hz}), 1.47$ (1H, tq, $J 12.9,3.9 \mathrm{~Hz}), 1.57$ (1H, bd, $J 9.0 \mathrm{~Hz}), 1.67$ (1H, ddd, J 11.7, 3.4, $1.5 \mathrm{~Hz}), 1.76(1 \mathrm{H}, \mathrm{dd}$, $J 12.7,2.7 \mathrm{~Hz}), 1.82(1 \mathrm{H}, \mathrm{ddd}, J 11.5,6.1 \mathrm{~Hz}), 1.88(1 \mathrm{H}, \mathrm{bd}$, $J 10.5 \mathrm{~Hz}), 2.29$ (1H, ddd, J 18.0, 6.1, 4.0 Hz), 2.35 (1H, dt, $J$ 13.0, $2.9 \mathrm{~Hz}), 2.54$ (1H, ddd, $J 18.0,11.5,7.09 \mathrm{~Hz}), 3.08$ (1H, bd, J 2.2 Hz), 3.42 (1H, bs), 4.69 (1H, dddd, J 13.0, 2.0, 2.0, $2.0 \mathrm{~Hz}) \cdot{ }^{13} \mathrm{C}-\mathrm{RMN}(125 \mathrm{MHz}, \mathrm{CDCl} 3), \delta 25.1\left(\mathrm{CH}_{2}\right)$, $25.3\left(\mathrm{CH}_{2}\right), 26.0\left(\mathrm{CH}_{3}\right), 28.4\left(\mathrm{CH}_{2}\right), 29.6\left(\mathrm{CH}_{2}\right), 31.4\left(\mathrm{CH}_{2}\right)$, $44.4\left(\mathrm{CH}_{2}\right), 68.1(\mathrm{CH}), 69.5(\mathrm{C}), 168.1(\mathrm{C}) . \mathrm{IR}$ (KBr film) $v_{\max } / \mathrm{cm}^{-1}:$ 1614. HRMS (EI): found 183,1259.; calcd. for $\mathrm{C}_{10} \mathrm{H}_{17} \mathrm{NO}_{2}\left(\mathrm{M}^{+\bullet}\right): 183.1259$.

(1R*,9aR*)-1-Hydroxy-1-methylperhydro-4-quinolizinone (13)

The same procedure was employed from 11a, affording 13 in $78 \%$ yield, as an yellow sirup. ${ }^{1} \mathrm{H}-\mathrm{RMN}(500 \mathrm{MHz}$, $\left.\mathrm{CDCl}_{3}\right), \delta 1.33(3 \mathrm{H}, \mathrm{s}), 1.36(2 \mathrm{H}, \mathrm{bt}, J 14.4 \mathrm{~Hz}), 1.44(1 \mathrm{H}, \mathrm{dq}$, $J 13.2,3.2 \mathrm{~Hz}), 1.64(1 \mathrm{H}, \mathrm{dd}, J 11.9,2.5 \mathrm{~Hz}), 1.76(1 \mathrm{H}, \mathrm{ddd}$, $J 16.6,10.7,5.6 \mathrm{~Hz}), 1.89(2 \mathrm{H}, \mathrm{m}), 1.95(1 \mathrm{H}, \mathrm{m}), 2.34(1 \mathrm{H}$, t, $J 5.4 \mathrm{~Hz}), 2.41(1 \mathrm{H}, \mathrm{dt}, J 11.5,4.2 \mathrm{~Hz}), 2.62(1 \mathrm{H}, \mathrm{ddd}, J$ $16.1,10.7,5.6 \mathrm{~Hz}), 3.07(1 \mathrm{H}$, bdd, $J 11.3,2.5 \mathrm{~Hz}), 3.45(1 \mathrm{H}$, sl), 4.79 (1H, dddd, $J 17.1,2.0,2.0,2.0 \mathrm{~Hz}) .{ }^{13} \mathrm{C}-\mathrm{RMN}(125$ $\left.\mathrm{MHz}, \mathrm{CDCl}_{3}\right), \delta: 24.3\left(\mathrm{CH}_{2}\right), 25.0\left(\mathrm{CH}_{2}\right), 26.2\left(\mathrm{CH}_{2}\right), 27.4$ $\left(\mathrm{CH}_{3}\right), 28.5\left(\mathrm{CH}_{2}\right), 33.3\left(\mathrm{CH}_{2}\right), 43.2\left(\mathrm{CH}_{2}\right), 65.5(\mathrm{CH}), 67.9$ (C), 169,1 (C). IR (KBr film) $v_{\text {max }} / \mathrm{cm}^{-1}: 1614$. HRMS (EI): found 183,1255; calcd. for $\mathrm{C}_{10} \mathrm{H}_{17} \mathrm{NO}_{2}\left(\mathrm{M}^{+*}\right)$ : 183.1259 .

( $\left.3 S^{*}\right)-1-E$ thy $l-3-\left[\left(1 S^{*}\right)-1-\right.$ hydrox $y-2$ methylpropyl]hexahydro-2-pyridinone (14a) and (3S*)-1ethyl-3-[(1R*)-1-hydroxy-2-methylpropyl]hexahydro-2pyridinone $(\mathbf{1 4 b})$

n-Butyllithium $\left(0.751 \mathrm{~mL}, 2.2 \mathrm{~mol} \mathrm{~L}^{-1}\right.$ solution in 
hexane) was added to a solution of diisopropylamine $(0.167$ $\mathrm{g}, 1.65 \mathrm{mmol})$ in dry $\mathrm{THF}(14.5 \mathrm{~mL})$ at $-78^{\circ} \mathrm{C}$ under argon atmosphere. The mixture was stirred for $30 \mathrm{~min}$. at $0{ }^{\circ} \mathrm{C}$, then cooled to $-78{ }^{\circ} \mathrm{C}$, followed by slow addition of $N$ ethylvalerolactam $(0.100 \mathrm{~g}, 0.787 \mathrm{mmol})$ in $3.0 \mathrm{~mL}$ of dry THF. The mixture was warmed to $0{ }^{\circ} \mathrm{C}$ and stirred for $1 \mathrm{~h}$. Isobutyraldehyde $(0.0624 \mathrm{~g}, 0.866 \mathrm{mmol})$ was added at $78{ }^{\circ} \mathrm{C}$ and warmed to $0{ }^{\circ} \mathrm{C}$. After $30 \mathrm{~min}, \mathrm{NH}_{4} \mathrm{Cl}(2.0 \mathrm{~mL})$ was added. The organic layer was separated, and the aqueous phase was extracted with $\operatorname{AcOEt}(3 \times 30 \mathrm{~mL})$. The combined organic layer was dried over $\mathrm{MgSO}_{4}$, filtered and concentrated under reduced pressure, affording a 3.9:1 mixture of 14a:14b in $75 \%$ yield. The mixture of diastereoisomers was separated by flash chromatography (hexane:AcOEt, 1:1) providing pure 14a (0.0935 g, $0.470 \mathrm{mmol}, 60 \%)$ and 14b (0.0239 g, $0.120 \mathrm{mmol}, 15 \%)$ as white crystals. $\mathbf{1 4 a}$. mp:34.3-35.4 ${ }^{\circ} \mathrm{C}{ }^{1} \mathrm{H}-\mathrm{RMN}\left(\mathrm{CDCl}_{3}\right.$, $300 \mathrm{MHz}) \delta 0.88(3 \mathrm{H}, \mathrm{d}, J 6.6 \mathrm{~Hz}), 1.05(3 \mathrm{H}, \mathrm{d}, J 6.6 \mathrm{~Hz})$, $1.13(3 \mathrm{H}, \mathrm{t}, J 7.3 \mathrm{~Hz}), 1.34-1.47(1 \mathrm{H}, \mathrm{m}), 1.72-1.83(4 \mathrm{H}, \mathrm{m})$, 1.84-1.96 (2H, m), 2.26 (1H, ddd, $J 11.4,9.5,5.9 \mathrm{~Hz}), 3.28-$ 3.33 (2H, m), 3.39 (2H, dq, $J 7.3,3.6 \mathrm{~Hz}), 3.58$ (1H, dd, $J$ 9.2, $2.6 \mathrm{~Hz}), 5.90(1 \mathrm{H}, \mathrm{s}) .{ }^{13} \mathrm{C}-\mathrm{RMN}\left(\mathrm{CDCl}_{3}, 75 \mathrm{MHz}\right) \delta$ : $12.0\left(\mathrm{CH}_{3}\right), 13.6\left(\mathrm{CH}_{3}\right), 20.1\left(\mathrm{CH}_{3}\right), 22.1\left(\mathrm{CH}_{2}\right), 23.7\left(\mathrm{CH}_{2}\right)$, $29.0(\mathrm{CH}), 42.1\left(\mathrm{CH}_{2}\right), 44.0(\mathrm{CH}), 47.1\left(\mathrm{CH}_{2}\right), 76.3(\mathrm{CH})$, 173.5 (C). IR (KBr film) $v_{\max } / \mathrm{cm}^{-1}: 3338,1610.14 b . \mathrm{mp}$ 63.8-64.4 ${ }^{\circ} \mathrm{C},{ }^{1} \mathrm{H}-\mathrm{RMN}\left(\mathrm{CDCl}_{3}, 300 \mathrm{MHz}\right) \delta 0.87(3 \mathrm{H}, \mathrm{d}, J$ $6.6 \mathrm{~Hz}), 1.02(3 \mathrm{H}, \mathrm{d}, J 6.6 \mathrm{~Hz}), 1.11(3 \mathrm{H}, \mathrm{dt}, J 7.3,1.5 \mathrm{~Hz})$, 1.65-1.83 (4H, m), 1.90-1.96 (1H, m), 2.47 (1H, dt, J 7.3, $4.4 \mathrm{~Hz}), 2.91$ (1H, bs), 3.22-3.34 (2H, m), 3.41 (2H, q, J 7.3 $\mathrm{Hz}), 3.93$ (1H, bdd, $J$ 8.8, $4.4 \mathrm{~Hz}) .{ }^{13} \mathrm{C}-\mathrm{RMN}\left(\mathrm{CDCl}_{3}, 75\right.$ MHz) $\delta: 12.3\left(\mathrm{CH}_{3}\right), 19.1\left(\mathrm{CH}_{3}\right), 19.4\left(\mathrm{CH}_{3}\right), 20.1\left(\mathrm{CH}_{2}\right)$, $22.4\left(\mathrm{CH}_{2}\right), 30.0(\mathrm{CH}), 42.1\left(\mathrm{CH}_{2}\right), 44.8(\mathrm{CH}), 46.9\left(\mathrm{CH}_{2}\right)$, $76.6(\mathrm{CH}), 171.7(\mathrm{C})$. IR (KBr film) $v_{\text {max }} / \mathrm{cm}^{-1}: 3423,1622$. The same procedure was performed using LiHMDS (LiHMDS was prepared employing HMDS instead of DIPA) as base affording a 4.4:1 diastereoisomeric mixture of 14a:14b in $60 \%$ combined yield.

(1R*,3R*,9aR*)-1-Hydroxy-3-[(1R*)-1-hydroxy-2methylpropyl]-1-methylperhydro-4-quinolizinone (16a)

The lithium enolate of $\mathbf{1 3}$ was generated as described above for $\delta$-valerolactam and the reaction with isobutyraldehyde afforded anti-16a:syn-16b in a 20:1 diastereoisomeric ratio mixture in $85 \%$ yield. $16 \boldsymbol{a}$. mp:146.0-146.5 ${ }^{\circ} \mathrm{C}{ }^{1} \mathrm{H}-\mathrm{RMN}\left(\mathrm{CDCl}_{3}, 300 \mathrm{MHz}\right) \delta 0.91$ $(3 \mathrm{H}, \mathrm{d}, J 6.6 \mathrm{~Hz}), 1.05(3 \mathrm{H}, \mathrm{d}, J 6.6 \mathrm{~Hz}), 1.25-1.27(1 \mathrm{H}, \mathrm{m})$, 1.34 (3H, s), 1.38-1.45 (3H, m), 1.54 (1H, dd, J 20.1, 13.6 $\mathrm{Hz}), 1.68-1.76$ (1H, m), 1.77-1.86 (2H, m), 1.92-1.97 (1H, m), 2.41 (1H, bt, J 12.5 Hz), 2.62-2.71 (3H, m), $3.08(1 \mathrm{H}$, bdd, $J 11.4,2.6 \mathrm{~Hz}), 3.61$ (1H, dd, $J 8.8,2.9 \mathrm{~Hz}), 4.81(1 \mathrm{H}$, bd, $J 11.7 \mathrm{~Hz}) .{ }^{13} \mathrm{C}-\mathrm{RMN}\left(\mathrm{CDCl}_{3}, 75 \mathrm{MHz}\right) \delta 13.9\left(\mathrm{CH}_{3}\right)$, $20.0\left(\mathrm{CH}_{3}\right), 23.8\left(\mathrm{CH}_{2}\right), 24.6\left(\mathrm{CH}_{2}\right), 25.6\left(\mathrm{CH}_{2}\right), 27.9\left(\mathrm{CH}_{3}\right)$, $29.2(\mathrm{CH}), 37.1\left(\mathrm{CH}_{2}\right), 39.1(\mathrm{CH}), 42.6\left(\mathrm{CH}_{2}\right), 64.7(\mathrm{CH})$, $68.1(\mathrm{C}), 76.4(\mathrm{CH}), 173.8(\mathrm{C})$. IR (KBr film) $v_{\text {max }} / \mathrm{cm}^{-1}$ : 3411, 1718, 1668. HRMS (EI): found 255,1835; calc. for $\mathrm{C}_{14} \mathrm{H}_{25} \mathrm{NO}_{3}\left(\mathrm{M}^{+\bullet}\right): 255,1834$.

Alternatively, the lithium enolate of $\mathbf{1 3}$ was generated as described for $\delta$-valerolactam. At $-78{ }^{\circ} \mathrm{C},\left({ }^{\mathrm{i} P O H}\right)_{3} \mathrm{TiCl}$ (3.5 equiv) was added dropwise with stirring over $5 \mathrm{~min}$, followed by addition of isobutyraldehyde (1.1 equiv) to gave 32:1 diastereoisomeric ratio mixture of anti-16a:syn$\mathbf{1 6 b}$ in $58 \%$ yield.

(1R*,3R*,9aR*)-1-Hydroxy-3-[(1S*)-1-hydroxy-2methylpropyl]-1-methylperhydro-4-quinolizinone (16b)

The lithium enolate of $\mathbf{1 3}$ was generated as described for $N$-ethylvalerolactam. At $-78^{\circ} \mathrm{C}$, TBSOTf (1.0 equiv.) was added dropwise with stirring and warmed to $0{ }^{\circ} \mathrm{C}$. After $2 \mathrm{~h}$ at $0{ }^{\circ} \mathrm{C}$, isobutyraldehyde (1.1 equiv.) and TMSOTf (1.1 equiv) were added providing a $1: 3$ diastereoisomeric ratio mixture of anti-16a: $s y n-\mathbf{1 6} \mathbf{b}$ in 70\% yield. 16b. mp: 148.7-149.5 ${ }^{\circ} \mathrm{C}{ }^{1} \mathrm{H}-\mathrm{RMN}$ (CD 3 OD, 300 MHz) $\delta 0.87(3 \mathrm{H}, \mathrm{d}, J 6.6 \mathrm{~Hz}), 1.02(3 \mathrm{H}, \mathrm{d}, J 6.6 \mathrm{~Hz}), 1.30$ $(3 \mathrm{H}, \mathrm{s}), 1.35-1.51(3 \mathrm{H}, \mathrm{m}), 1.55-1.74(4 \mathrm{H}, \mathrm{m}), 1.79-1.89$ (3H, m), 2.48 (1H, dt, J 13.2, 2.6 Hz), 2.74 (1H, ddd, J 12.5, $5.9,1.8 \mathrm{~Hz}), 3.14$ (1H, dd, $J 11.4,2.6 \mathrm{~Hz}), 3.30$ (1H, quint., $J 1.5 \mathrm{~Hz}), 3.94$ (1H, dd, J 9.9, $1.8 \mathrm{~Hz}$ ), 4.71 (1H, bd, J 13.2 $\mathrm{Hz}) .{ }^{13} \mathrm{C}-\mathrm{RMN}\left(\mathrm{CD}_{3} \mathrm{OD}, 75 \mathrm{MHz}\right) \delta 19.3\left(\mathrm{CH}_{3}\right), 20.6\left(\mathrm{CH}_{3}\right)$, $24.8\left(\mathrm{CH}_{2}\right), 26.0\left(\mathrm{CH}_{2}\right), 26.9\left(\mathrm{CH}_{2}\right), 27.7\left(\mathrm{CH}_{3}\right), 31.9(\mathrm{CH})$, $33.9\left(\mathrm{CH}_{2}\right), 41.3(\mathrm{CH}), 44.0\left(\mathrm{CH}_{2}\right), 65.8(\mathrm{CH}), 68.8(\mathrm{C})$, $77.4(\mathrm{CH}), 173.4(\mathrm{C})$. IR (KBr film) $v_{\max } / \mathrm{cm}^{-1}: 3400,3370$, 1691. HRMS (EI): found 255,1833; calcd. for $\mathrm{C}_{14} \mathrm{H}_{25} \mathrm{NO}_{3}$ $\left(\mathrm{M}^{+\bullet}\right): 255,1834$.

(1R*,9aR*) - 1-Hydroxy-1 - me thyl-3 - [ (E) - 2 methylpropylidene]perhydro-4-quinolizinone (17)

To a solution of the aldol adduct $16 \mathbf{a}(47 \mathrm{mg}, 0.18$ $\mathrm{mmol})$ in dry toluene $(4.5 \mathrm{~mL})$ was added DCC (46 mg, $0.22 \mathrm{mmol}$ ) and $\mathrm{CuCl}$ (34 $\mathrm{mg}, 0.34 \mathrm{mmol}$ ), and the resulting mixture was heated to reflux in a Pyrex tube for $24 \mathrm{~h}$. After this time, dilute aqueous ammonia $(10 \mathrm{~mL})$ was added, and the mixture was extracted with $\operatorname{AcOEt}(3 \times 20 \mathrm{~mL})$. The organic layer was dried with $\mathrm{MgSO}_{4}$ and concentrated under reduced pressure. The crude was purified through flash chromatography (petroleum ether:AcOEt, $3: 1$ ) to gave $(E)$ 17 (41 mg, $0.17 \mathrm{mmol}$ ) in $95 \%$ yield as a colorless oil. ${ }^{1} \mathrm{H}-$ $\mathrm{RMN}\left(\mathrm{CDCl}_{3}, 300 \mathrm{MHz}\right) \delta 1.02(3 \mathrm{H}, \mathrm{d}, J 6.2 \mathrm{~Hz}), 1.04(3 \mathrm{H}$, d, J 6.2 Hz), $1.28(3 \mathrm{H}, \mathrm{s}), 1.21-1.36(1 \mathrm{H}, \mathrm{m}), 1.43-1.71(3 \mathrm{H}$, m), 1.85-1.98 (2H, m), 2.47 (1H, d, J 15.0 Hz), 2.44-2.52 
(1H, m), 2.54-2.64 (1H, m), 2.63 (1H, d, J $15.0 \mathrm{~Hz}), 3.23$ $(1 \mathrm{H}, \mathrm{d}, J 12.1 \mathrm{~Hz}), 3.54(1 \mathrm{H}, \mathrm{m}), 4.82$ (1H, dq, $J$ 12.8, 3.0 $\mathrm{Hz}), 6.81(1 \mathrm{H}, \mathrm{bd}, J 9.9 \mathrm{~Hz}) .{ }^{13} \mathrm{C}-\mathrm{RMN}\left(\mathrm{CDCl}_{3}, 75 \mathrm{MHz}\right) \delta$ : $22.0\left(\mathrm{CH}_{3}\right), 22.4\left(\mathrm{CH}_{3}\right), 25.0\left(\mathrm{CH}_{3}\right), 25.0\left(\mathrm{CH}_{2}\right), 25.4\left(\mathrm{CH}_{2}\right)$, $27.1(\mathrm{CH}), 29.4\left(\mathrm{CH}_{2}\right), 35.5\left(\mathrm{CH}_{2}\right), 45.1\left(\mathrm{CH}_{2}\right), 68.0(\mathrm{CH})$, 69.2 (C), 123.6 (C), $148.6(\mathrm{CH}), 163.4$ (C). HRMS (EI): found 237.1727; calcd. for $\mathrm{C}_{14} \mathrm{H}_{23} \mathrm{NO}_{2}\left(\mathrm{M}^{+*}\right)$ : 237.1729 .

( 1R*,9aR*) - 1-Hydroxy-1-methyl-3 - [ (Z) - 2 methylpropylidene Jperhydro-4-quinolizinone (18)

The same procedure was performed using $\mathbf{1 6 b}$ to furnish 18 as the sole product in 95\% yield, after column chromatography eluting with petroleum ether:AcOEt $(3: 1)$. ${ }^{1} \mathrm{H}-\mathrm{RMN}\left(\mathrm{CDCl}_{3}, 300 \mathrm{MHz}\right) \delta 1.00(3 \mathrm{H}, \mathrm{d}, J 6.6 \mathrm{~Hz}), 1.06$ $(3 \mathrm{H}, \mathrm{d}, J 6.6 \mathrm{~Hz}), 1.31(3 \mathrm{H}, \mathrm{s}), 1.36-1.52(2 \mathrm{H}, \mathrm{m}), 1.65(2 \mathrm{H}$, d, $J 29.4 \mathrm{~Hz}), 1.86-2.22$ (2H, m), 2.33 (1H, d, J $13.2 \mathrm{~Hz})$, $2.42(1 \mathrm{H}, \mathrm{dt}, J 13.2,2.9 \mathrm{~Hz}), 2.54(1 \mathrm{H}, \mathrm{dd}, J 13.2,1.5 \mathrm{~Hz})$, 3.08 (1H, dd, J 11.8, 2.9 Hz), 3.54-3.63 (1H, m), 4.84, (1H, ddd, $J 13.2,2.9,1.5 \mathrm{~Hz}), 5.60(1 \mathrm{H}, \mathrm{dd}, J 9.9,1.5 \mathrm{~Hz}) .{ }^{13} \mathrm{C}-$ $\mathrm{RMN}\left(\mathrm{CDCl}_{3}, 75 \mathrm{MHz}\right) \delta 22.6\left(\mathrm{CH}_{3}\right), 23.2\left(\mathrm{CH}_{3}\right), 24.4$ $\left(\mathrm{CH}_{2}\right), 25.1\left(\mathrm{CH}_{2}\right), 26.2\left(\mathrm{CH}_{3}\right), 26.3\left(\mathrm{CH}_{2}\right), 27.9(\mathrm{CH}), 42.7$ $\left(\mathrm{CH}_{2}\right), 45.8\left(\mathrm{CH}_{2}\right), 66.1(\mathrm{CH}), 68.7(\mathrm{C}), 123.1(\mathrm{C}), 151.6$ (CH), 163.7 (C). HRMS (EI): found 237.1727; calcd. for $\mathrm{C}_{14} \mathrm{H}_{23} \mathrm{NO}_{2}\left(\mathrm{M}^{+\bullet}\right): 237.1729$.

Alternatively, lactam 16b (0.340 g, $1.33 \mathrm{mmol})$ was dissolved in dry $\mathrm{CHCl}_{2}(14.8 \mathrm{~mL})$, with a single crystal of DMAP, cooled to $-40{ }^{\circ} \mathrm{C}$ under argon atmosphere, and treated with trifluoroacetic anhydride $(0.565 \mathrm{~mL}$, $4.00 \mathrm{mmol})$ and $1.00 \mathrm{~mL}$ of DBU $(6.66 \mathrm{mmol})$. The reaction mixture was warmed slowly (over $1 \mathrm{~h}$ ) to $0{ }^{\circ} \mathrm{C}$, then treated with a second portion of DBU $(1.00 \mathrm{~mL}, 6.66 \mathrm{mmol})$ and allowed to warm to room temperature. Dilute with water $(100 \mathrm{~mL})$ and the mixture was extracted with AcOEt $(3 \mathrm{x}$ $100 \mathrm{~mL}$ ). The organic layer was dried with $\mathrm{MgSO}_{4}$ and concentrated under reduced pressure. The crude was purified through flash chromatography (petroleum ether:AcOEt, 3:1) to gave (Z)-18 in $\mathbf{8 0 \%}$ yield.

\section{N-Ethyl-3-[(E)-2-methylpropylidene]-2-piperidinone} (15a)

The same procedure described for $\mathbf{1 7}$ was performed employing 14a to furnish 15a as the sole product in $88 \%$ yield, after column chromatography eluting with hexane:AcOEt (1:1). ${ }^{1} \mathrm{H}-\mathrm{RMN}\left(\mathrm{CDCl}_{3}, 300 \mathrm{MHz}\right) \delta 0.99$ $(6 \mathrm{H}, \mathrm{d}, J 6.6 \mathrm{~Hz}), 1.13(3 \mathrm{H}, \mathrm{t}, J 7.0 \mathrm{~Hz}), 1.79-1.87(2 \mathrm{H}, \mathrm{m})$, $2.46(2 \mathrm{H}$, ddd, $J 5.9,5.9,1.8 \mathrm{~Hz}), 2.48-2.60(2 \mathrm{H}, \mathrm{m}), 3.32$ $(2 \mathrm{H}, \mathrm{dd}, J 5.9,5.9 \mathrm{~Hz}), 3.46(1 \mathrm{H}, \mathrm{q}, J 7.0 \mathrm{~Hz}), 6.65(1 \mathrm{H}, \mathrm{dt}$, $J$ 9.9, $1.8 \mathrm{~Hz}) .{ }^{13} \mathrm{C}-\mathrm{RMN}\left(\mathrm{CDCl}_{3}, 75 \mathrm{MHz}\right) \delta: 12.2\left(\mathrm{CH}_{3}\right)$, $22.9\left(2 \mathrm{xCH}_{3}\right), 24.6\left(\mathrm{CH}_{2}\right), 24.9\left(\mathrm{CH}_{2}\right), 27.1(\mathrm{CH}), 42.6\left(\mathrm{CH}_{2}\right)$,
$47.1\left(\mathrm{CH}_{2}\right), 126.7$ (C), $144.5(\mathrm{CH}), 164.7$ (C) IR (KBr film) $v_{\max } / \mathrm{cm}^{-1}: 1662,1610$. HRMS (EI): found 181,1461; calcd. for $\mathrm{C}_{11} \mathrm{H}_{19} \mathrm{NO}\left(\mathrm{M}^{+\bullet}\right): 181.1467$.

1-Ethyl-3-[(Z)-2-methylpropylidene]-2-piperidinone (15b)

The same procedure described for $\mathbf{1 7}$ was performed employing 14b to furnish $\mathbf{1 5 b}$ as the sole product in $87 \%$ yield, after column chromatography eluting with hexane:AcOEt (1:1). ${ }^{1} \mathrm{H}-\mathrm{RMN}\left(\mathrm{CDCl}_{3}, 300 \mathrm{MHz}\right) \delta 0.98$ $(6 \mathrm{H}, \mathrm{d}, J 6.6 \mathrm{~Hz}), 1.14(3 \mathrm{H}, \mathrm{t}, J 7.3 \mathrm{~Hz}), 1.82-1.90(2 \mathrm{H}, \mathrm{m})$, 2.38 (2H, ddd, J 6.2, 6.2, $1.5 \mathrm{~Hz}), 3.29(2 \mathrm{H}, \mathrm{t}, J 6.2 \mathrm{~Hz})$, $3.43(2 \mathrm{H}, \mathrm{q}, J 7.3 \mathrm{~Hz}), 3.66(1 \mathrm{H}, \mathrm{dq}, J 6.5,2.9 \mathrm{~Hz}), 5.49(1 \mathrm{H}$, bd, J 9.5 Hz). ${ }^{13} \mathrm{C}-\mathrm{RMN}\left(\mathrm{CDCl}_{3}, 75 \mathrm{MHz}\right) \delta 12.2\left(\mathrm{CH}_{3}\right)$, $22.9\left(2 \mathrm{xCH}_{3}\right), 23.8\left(\mathrm{CH}_{2}\right), 27.6(\mathrm{CH}), 32.5\left(\mathrm{CH}_{2}\right), 41.7\left(\mathrm{CH}_{2}\right)$, $47.2\left(\mathrm{CH}_{2}\right), 126.5(\mathrm{C}), 148.0(\mathrm{CH}), 164.8(\mathrm{C}) . \mathrm{IV}(\mathrm{KBr}$ film $)$ $v_{\max } / \mathrm{cm}^{-1}: 1660,1620$. HRMS (EI): found 181,1466; calcd. for $\mathrm{C}_{11} \mathrm{H}_{19} \mathrm{NO}\left(\mathrm{M}^{+*}\right): 181.1467$.

Preparation of lithium aluminum hydride solution in THF

Solution of $\mathrm{LiAlH}_{4}(5.0 \mathrm{~g}, 0.125 \mathrm{~mol})$ in THF was prepared by adding an excess of the hydride to dry THF $(80.0 \mathrm{~mL})$ and stirred the mixture at least $2 \mathrm{~h}$ under a dry argon atmosphere. The resulting solution was then filtered under a slight positive argon pressure through a $2 \mathrm{~cm}$ bed of tightly packed Celite prepared on a Schlenk system. After following the above procedure, a crystal-clear 1.55 mol L-1 solution was obtained.

\section{Homopumiliotoxin $223 G$ hydrochloride (1)}

To a solution of $\mathbf{1 8}(30 \mathrm{mg}, 0.13 \mathrm{mmol})$ in THF $(1.0 \mathrm{~mL})$ was added a solution of aluminum hydride (3.0 equiv., previously prepared by mixing 1 equiv. of $\mathrm{AlCl}_{3}$ and 3 equiv. of $\mathrm{LiAlH}_{4}$ solution in THF) at room temperature. After $10 \mathrm{~min}$, the reaction was quenched with satured aqueous sodium sulfate solution and filtered. The solids were washed with $\mathrm{CH}_{2} \mathrm{Cl}_{2}$ and acidified with $\mathrm{HCl} / \mathrm{MeOH}$ $(10 \%)$ to resulting solution effected complete conversion to hydrochloride salt, and evaporation in reduced pressure afforded the crude $\mathbf{1}$ which was purified through flash chromatography eluting with $\mathrm{CHCl}_{3}: \mathrm{MeOH}: \mathrm{NH}_{4} \mathrm{OH}$ (200:90:1). Reacidification with $\mathrm{HCl} / \mathrm{MeOH}$ afforded pure 1. $\mathrm{HCl}(0.029 \mathrm{~g}, 0.11 \mathrm{mmol}) 82 \%$ yield as pale crystal. 1. $\mathrm{HCl}$. mp: $183-184{ }^{\circ} \mathrm{C}{ }^{1} \mathrm{H}-\mathrm{RMN}\left(\mathrm{CD}_{3} \mathrm{OD}, 500 \mathrm{MHz}\right) \delta$ $0.86(3 \mathrm{H}, \mathrm{d}, J 6.7 \mathrm{~Hz}), 0.96(3 \mathrm{H}, \mathrm{d}, J 6.7 \mathrm{~Hz}), 1.15(3 \mathrm{H}, \mathrm{s})$, 1.18-1.25 (1H, m), 1.48 (1H, tt, J 13.1, 3.7 Hz), 1.57-1.67 (2H, m), 1.77-1.86 (2H, m), 1.98 (1H, bd, J 14.3 Hz), 2.19 $(1 \mathrm{H}, \mathrm{dd}, J 14.3,1.8 \mathrm{~Hz}), 2.34(1 \mathrm{H}, \mathrm{bd}, J 14.0 \mathrm{~Hz}), 2.53-2.58$ $(1 \mathrm{H}, \mathrm{m}), 2.93(1 \mathrm{H}, \mathrm{dt}, J 13.1,3.4 \mathrm{~Hz}), 3.05$ (1H, dd, J 11.9, 
$3.1 \mathrm{~Hz}), 3.21(1 \mathrm{H}, \mathrm{q}, J 1.8 \mathrm{~Hz}), 3.33(1 \mathrm{H}, \mathrm{tt}, J 13.1,1.8 \mathrm{~Hz})$, $4.02(1 \mathrm{H}, \mathrm{dd}, J 13.4,1.5 \mathrm{~Hz}), 5.24(1 \mathrm{H}, \mathrm{bd}, J 9.8 \mathrm{~Hz})$. ${ }^{13} \mathrm{C}-\mathrm{RMN}\left(\mathrm{CDCl}_{3}, 75 \mathrm{MHz}\right) \delta 23.1\left(\mathrm{CH}_{2}\right), 23.2\left(\mathrm{CH}_{3}\right), 23.6$ $\left(\mathrm{CH}_{3}\right), 24.3\left(\mathrm{CH}_{2}\right), 24.3\left(\mathrm{CH}_{2}\right), 26.0\left(\mathrm{CH}_{3}\right), 27.9(\mathrm{CH}), 47.8$ $\left(\mathrm{CH}_{2}\right), 55.8\left(\mathrm{CH}_{2}\right), 56.5\left(\mathrm{CH}_{2}\right), 70.0(\mathrm{C}), 71.0(\mathrm{CH}), 124.1$ (C), 140.7 (CH). HRMS (EI): found 223,1941; calcd. for $\mathrm{C}_{14} \mathrm{H}_{25} \mathrm{NO}\left(\mathrm{M}^{+\bullet}-\mathrm{HCl}\right): 223,1936$.

\section{(E)-1 Hydrochloride}

The same procedure was employed to 17 affording $(E)$ $\mathbf{1}$ in $80 \%$ yield as a colorless crystal. (E)-1. mp:203-204 ${ }^{\circ} \mathrm{C}$ ${ }^{1} \mathrm{H}-\mathrm{RMN}\left(\mathrm{CDCl}_{3}, 500 \mathrm{MHz}\right) \delta 0.93(3 \mathrm{H}, \mathrm{d}, J 6.2 \mathrm{~Hz}), 0.95$ $(3 \mathrm{H}, \mathrm{d}, J 6.2 \mathrm{~Hz}), 1.26(3 \mathrm{H}, \mathrm{s}), 1.11-2.00(5 \mathrm{H}, \mathrm{m}), 2.25-2.62$ $(2 \mathrm{H}, \mathrm{m}), 2.58-2.70(1 \mathrm{H}, \mathrm{d}, J 13.0 \mathrm{~Hz}), 2.99-3.05(2 \mathrm{H}, \mathrm{m})$, 3.18-3.24 (1H, m), $3.43(1 \mathrm{H}, \mathrm{bd}, J 13.1 \mathrm{~Hz}), 3.63(1 \mathrm{H}, \mathrm{dd}, J$ 13.1, $9.8 \mathrm{~Hz}), 5.54(1 \mathrm{H}, \mathrm{d}, J 9.8 \mathrm{~Hz}) .{ }^{13} \mathrm{C}-\mathrm{RMN}\left(\mathrm{CDCl}_{3}, 75\right.$ MHz) $\delta 21.1\left(\mathrm{CH}_{2}\right), 22.9\left(\mathrm{CH}_{3}\right), 23.0\left(\mathrm{CH}_{3}\right), 23.4\left(\mathrm{CH}_{2}\right)$, $24.6\left(\mathrm{CH}_{2}\right), 24.7\left(\mathrm{CH}_{3}\right), 27.9(\mathrm{CH}), 43.1\left(\mathrm{CH}_{2}\right), 57.1\left(\mathrm{CH}_{2}\right)$, $62.4\left(\mathrm{CH}_{2}\right), 70.7(\mathrm{C}), 71.8(\mathrm{CH}), 124.8(\mathrm{C}), 141.6(\mathrm{CH})$. HRMS (IE): found 223,1940; calcd. for $\mathrm{C}_{14} \mathrm{H}_{25} \mathrm{NO}\left(\mathrm{M}^{+*}\right.$ $\mathrm{HCl}): 223,1936$.

\section{References}

1. Daly, J. W.; Braz. J. Med. Biol. Res. 1995, 28, 1033; Daly, J. W.; J. Nat. Prod. 1998, 61, 162.

2. Tokuyama, T.; Nishimori, N.; Shimada, A.; Tetrahedron 1987, 43, 643.

3. Aoyagi, S.; Hasegawa, Y.; Hirashima, S.; Kibayashi, C.; Tetrahedron Lett. 1998, 39, 2149.

4. Santos, L. S.; Pilli, R. A.; Tetrahedron Lett. 2001, 41, 6999.

5. Martin, S. F.; Corbett, J. W.; Synthesis 1992, 1, 55; Morimoto, Y.; Nishida, K., Hayashi, Y.; Shirahama, H.; Tetrahedron Lett.
1993, 34, 5773; Pichon, M.; Figadére, B.; Cavé, A.; Tetrahedron Lett. 1996, 37, 7963; Morimoto, Y.; Iwahashi, M.; Synlett 1995, 1221; Zanardi, F.; Battistini, L.; Rassu, G.; Pinna, L.; Mor, M.; Culeddu, N.; Casiraghi, G.; J. Org. Chem. 1998, 63, 1368; Martin, S. F.; Barr, K. J.; Smith, D. W.; Bur, S. K.; J. Am. Chem. Soc. 1999, 121, 6990.

6. de Oliveira, M. C. F.; Santos, L. S.; Pilli, R. A.; Tetrahedron Lett. 2001, 41, 6995.

7. Bur, S. K.; Martin, S. F.; Org. Lett. 2000, 2, 3445.

8. D’Oca, M. G. M.; R. A. Pilli; Vencato, I.; Tetrahedron Lett. 2000, 41, 9709.

9. Seebach, D.; Lamatsch, B.; Helv. Chim. Acta 1992, 75, 1095; Kupfer, R.; Würthwein, E.-U.; Nagel, M.; Allmann, R.; Chem. Ber. 1985, 118, 643.

10. Jones, G. B.; Chapman, B. J.; Synthesis 1995, 475.

11. Corey, E. J.; Andersen, N. H.; Carlson, R. M.; Paust, J.; Vedjes, E.; Vlattas, I.; Winter, R. E. K.; J. Am. Chem. Soc. 1968, 90, 3245 .

12. Thorton, E. R.; Stormes, M. N.; J. Org. Chem. 1991, 56, 2489.

13. Gaussian 98, Gaussian, Inc.: Pittsburgh, PA, 1998.

14. Amos, R. A.; Katzenellenbogen, J. A.; J. Org. Chem. 1978, 43, 560.

15. Stork, G.; Shiner, C. S.; Winkler, J. D.; J. Am. Chem. Soc. 1982, 104, 310.

16. Fox, D. N. A.; Lathbury, D.; Mahon, M. F.; Molloy, K. C.; Gallagher, T.; J. Am. Chem. Soc. 1991, 113, 2652.

18. D’Oca, M G. M.; Pilli, R. A.; Pardini, V. L.; Curi, D.; Comninos, F. C. M.; J. Braz. Chem. Soc. 2001, 12, 507.

19. Casiraghi, G.; Rassu, G.; Synthesis 1995, 607.

Received: June 3, 2003 Published on the web: December 9, 2003

FAPESP helped in meeting the publication costs of this article. 